Marquette University

e-Publications@Marquette

$2-1-2017$

\title{
The Impact of Education on Political Ideology: Evidence from European Compulsory Education Reforms
}

Andrew G. Meyer

Marquette University, andrew.meyer@marquette.edu

NOTICE: this is the author's version of a work that was accepted for publication in Economics of Education Review. Changes resulting from the publishing process, such as peer review, editing, corrections, structural formatting, and other quality control mechanisms may not be reflected in this document. Changes may have been made to this work since it was submitted for publication. A definitive version was subsequently published in Economics of Education Review, Vol. 56, (February 2017): 9-23. DOI. (C) 2017 Elsevier. Used with permission. 


\title{
e-Publications@Marquette
}

\section{Economics Faculty Research and Publications/College of Business Administration}

This paper is NOT THE PUBLISHED VERSION; but the author's final, peer-reviewed manuscript. The published version may be accessed by following the link in th citation below.

Economics of Education Review, Vol. 56 (February 2017): 9-23. O․ This article is (C) Elsevier and permission has been granted for this version to appear in e-Publications@Marquette. Elsevier does not grant permission for this article to be further copied/distributed or hosted elsewhere without the express permission from Elsevier.

\section{The impact of education on political ideology: Evidence from European compulsory education reforms}

Andrew G. Meyer

Department of Economics, Marquette University, 606 North 13th St., Milwaukee, WI

\begin{abstract}
Previous research documents a correlation between education and political ideology, usually indicating a positive relationship between education and left-wing political views. In this paper, I examine to what extent this association is causal. I merge political ideology data from 25 waves of Eurobarometer surveys with information on 18 educational reforms in 11 European countries. I then instrument for educational attainment with a regression discontinuity design that estimates the increase in education due to compulsory educational reforms. Notably, it appears that omitted variables bias is important here. I find a significant causal effect of education moving individuals to the right when properly addressing the endogeneity whereas there is a significant association between education and left-wing political ideology when treating education as exogenous. I find that on average, among the individuals compelled into additional education from these specific reforms, an
\end{abstract}


additional year of education moves individuals to the right of the political continuum by about 5-6\%. However, I also find no evidence of a causal effect on political ideology for a subgroup of countries.

\section{Keywords}

Education, Political ideology, Europe, Compulsory education reforms

\section{Introduction}

Researchers have long been interested in the effect of education on political ideology. Most previous evidence suggests that education is associated with a more liberal ideology (Dunn, 2011; Weakliem, 2002). Moreover, it is often stated or implied that education causes individuals to move to the political left (for example, Dunn, 2011; Weakliem, 2002; Weil, 1985). However, to the author's knowledge, previous studies on political ideology have not dealt with the endogeneity of education. Specifically, previous cross-sectional research may suffer from omitted variables bias because there are likely unobserved factors that affect political ideology and lead individuals to attain higher levels of education. For example, innate personality characteristics or the political ideology of one's parents are unobserved and can affect both educational attainment and one's own political ideology. Perhaps more worrisome is that it is unclear what the direction of the bias in previous studies would be. There are plausible stories as to how these unobserved factors could push one either to the political right or to the left while simultaneously affecting educational attainment. Thus, previous studies are limited in their ability to inform us on what would happen to political ideology in an alternative world where individuals are compelled into more education.

In contrast, this paper contributes to the literature by estimating the causal effect of education on political ideology as measured by self-identified left-right placement. The analysis overcomes the endogeneity of education through leveraging changes in compulsory education laws in 20th century Europe. The key feature of these law changes is that individuals were forced into additional education rather than self-selecting into more education. This exogenous shift in educational attainment can then be utilized to identify the effect of education on the outcome of interest. This instrumental variables (IV) approach has now been firmly established in the literature and has been utilized to explain the impact of education on a wide variety of outcomes.

Recent research suggests that the left-right scale as a construct is problematic. Specifically, Bauer, Barbera, Ackermann, and Venetz (2015)argue that the left-right scale is a vague concept and empirical relationships will be biased as a result. In particular, the authors provide evidence that education is endogenous to self-placement on the left-right political scale in Germany. An omitted variable (the meaning that individuals attach to the concepts of political "left" and "right") is correlated with education and self-placement on the left-right scale. In the typical analysis of the association between 
education and left-right identity, we would not know "whether education affects ideology directly or merely through the different associations it triggers within respondents" (Bauer et al., 2015). This is the benefit of the identification strategy regression employed in the present paper. Rather than simply using the reported level of education, I estimate educational attainment utilizing a regression discontinuity design (RDD) that exploits the timing of compulsory educational reforms. One group of individuals was born just prior to a reform and another group of individuals was born just after a reform. After controlling for cohort trends, unobserved characteristics such as conceptual associations should be on average the same across these two groups. Thus, I am plausibly able to overcome the omitted variables problem detailed in Bauer et al. (2015).

Supporting the concerns of Bauer et al. (2015), I do find that the observed association between education and left-right political identity from a standard OLS regression is quite different from the causal relationship estimated utilizing the fuzzy RDD. There is a small but highly statistically significant association between education and left-wing identity in the observational regressions that treat education as exogenous. However, once leveraging the educational reforms as instruments for endogenous educational attainment, I find that education significantly moves individuals to the right in their political identities. Among individuals who were affected by the educational reforms (the compliers), an additional year of education moves an individual to the right by approximately $0.2-0.4$ points on a 10 point scale $(4 \%-8 \%$ relative to sample mean) depending on the specification, with most estimates falling near 0.25 (5\% relative to sample mean). I primarily utilize parametric specifications of a fuzzy RDD and find that the results are robust to linear and quadratic controls and to the sample bandwidth chosen. However, I also use nonparametric local linear regressions to confirm the results.

There are several theses from the political science and sociology literatures regarding the effect of educational attainment on political identity. As explained by Dunn (2011), these theories include "the self-interest thesis, the developmental thesis and the socialization thesis." The self-interest thesis reasons that those who attain higher levels of education are likely to earn higher incomes, which attracts them to a right-wing identity out of self-interest. As explained by Dunn (2011), this thesis can explain the traditional European association of higher education leading to a right-wing identification. Powdthavee and Oswald (2014) provide an analytical framework in which a rational voter trades off a desire for low taxes with a desire for a public good. They show that an increase in income can theoretically affect left-right political affiliation for such a utility maximizing agent. Powdthavee and Oswald (2014) then provide evidence that an exogenous shock to income through winning the lottery leads to significant movement to the right in political affiliation in the UK, supporting the idea that individuals act out of self-interest when voting. 
In contrast, the developmental thesis predicts that more education will lead to more of a left-wing political identity. In this thesis, education expands one's perspective and stimulates cognitive growth, leading to a more liberal ideology (Phelan, Link, Stueve, \& Moore, 1995). Finally, the socialization thesis maintains that political attitudes are transmitted to students through social learning processes. Students learn about society's attitudes through the behaviors that are modeled and reinforced in the educational system. A leading specific example of the socialization thesis is Weakliem's (2002) core values thesis. In this theory, education serves to increase the commitment to society's core values and institutions. Thus, more education would tend to move individuals to the right in predominantly conservative societies and to the left in predominantly liberal societies.

Concerning the aforementioned theories, the primary finding in this paper that increased educational attainment tends to move individuals to the right of the political spectrum could be consistent with either the self-interest thesis or the socialization thesis and is inconsistent with the developmental thesis. Closer examination of individual countries reveals most support for the self-interest thesis. Specifically, education tends to have a stronger causal effect on political ideology in countries where previous research has shown the reforms to be effective in increasing earnings and no causal effect in countries where research has shown the reforms to not affect earnings.

Aside from the contribution to the literature on the relationship between educational attainment and political attitudes, this paper adds to the growing literature concerning non-pecuniary effects of education. Most often, researchers use changes in compulsory education laws as a source of exogenous variation to identify the effects of interest. Much of this compulsory education literature has focused on labor market outcomes such as income and employment (Aakvik, Salvanes, \& Vaage, 2010; Acemoglu and Angrist, 2001; Angrist \& Krueger, 1991; Brunello, Fort, \& Weber, 2009; Meghir and Palme, 2005; Oreopoulos, 2006a, b). More recently, non-pecuniary effects of education are receiving more attention (Oreopoulos \& Salvanes, 2011). For example, increases in education have been shown to reduce crime (Hjalmarsson, Holmlund, \& Lindquist, 2015; Lochner and Moretti, 2004; Machin, Marie, \& Vujic, 2011), reduce teenage births (Black, Devereux, \& Salvanes, 2008), improve health outcomes 1 (Gathmann, Jürges, \& Reinhold, 2015; Lleras-Muney, 2005; van Kippersluis, O'Donnell, \& van Doorslaer, 2011), and increase pro-environmental behavior (Meyer, 2015).

In the political realm, Milligan, Moretti, and Oreopoulos (2004) and Dee (2004) find that increases in education cause political involvement and voting to increase. However, there are also mixed results in this area. Siedler (2010)finds little evidence of a causal effect of education on political behavior in Germany. Borgonovi, d'Hombres, and Hoskins (2010) pool reforms from 15 European countries and find that education increases political information acquisition but has no effect on voter turnout. $\underline{\mathrm{Di}}$ 
Pietro and Delprato (2009) )examine the effects of a compulsory education reform in Italy on a number of civic outcomes. The authors find a positive and significant effect on interest in politics, a negative and significant effect on the stated justifiability of not returning lost money to an owner and insignificant effects on the justifiability of not paying a ticket on a public transport vehicle and of not leaving one's name for the owner of a car one accidentally scraped, and an insignificant effect on the stated importance of the problem of tax evasion. Most recently, Persson, Lindgren, and Oskarsson (2016), leverage exogenous variation in school entry age in Greece, Norway, Slovenia, and Sweden to estimate the casual effect of the ninth year of education; the authors find no significant effect on political participation, democratic values, or political knowledge.

More generally, this study contributes to the literature that analyzes the determinants of voting intentions and support for politicians. Most of this work concentrates on how economic conditions affect voting intentions - often termed economic voting. For example, Veiga and Veiga (2004) find that economic conditions are important in determining support for right-wing and left-wing governments in Portugal. Sakurai and Menezes-Filho (2008) and Cassette, Farvaque, and Hericourt (2013) examine how local public spending affect municipal elections in Brazil and France, respectively. Yet, the approach in the present paper differs because it concentrates on a key individual-level determinant of political identity rather than national or local factors. The present results do suggest, however, that voting behavior could be influenced by public policies that change the level of required education. For example, any public policies that reduce the number of high school dropouts could affect political ideology. The results suggest that the effects would be largest in cases where the extra education is effective in increasing earnings of the compliers.

\section{Data}

The analysis in this paper requires information about left-right political ideology and compulsory education laws. 25 waves of Eurobarometer surveys provide the data on left-right political ideology and several recent papers provide the needed information about compulsory education laws. The European Commission regularly conducts population representative public opinion surveys of European Citizens; these are Eurobarometer surveys. I identify 25 waves of Eurobarometer surveys conducted between October 2004 and March 2012 that contain a question about left-right political identification. 2 Each wave collects data over a span of 1 to 3 months during the months of SeptemberMay. - All waves utilized face-to-face interviews, where interviewers followed uniform protocols. Each of the waves completed interviews with approximately 1000 individuals from each country and no more than one individual was interviewed from each household. In addition to the left-right ideology

question, interviewers collect several demographic variables including gender, age, and age when the individual left formal education. 4 As in Meyer (2015), I assume that educational attainment increases 
only until age 25 and exclude those who report an age of 36 or higher when they stopped full-time education. $\underline{5}$ Using the age when an individual stops education as a proxy of educational attainment is not a perfect measure because of possible gaps in one's education. However, this will only bias the estimated effect of reform on education if there are more people with gaps before or after a reform on average.

Following Borgonovi et al. (2010), Brunello et al. (2009), Brunello, Fabbri, and Fort (2013), Gathmann et al. (2015), and Meyer (2015), I elect to pool multiple educational reforms that occurred in 20th Century Europe. I begin with the group of reforms detailed in Gathmann et al. (2015); these reforms were implemented between 1900 and 1980.6 I then add the three remaining country-level reforms from Brunello et al. (2009) that fall within this time period. 7 This results in a list of 18 reforms from 11 Western European countries, which are summarized in Table 1. All of these reforms have been leveraged as instruments in multiple studies. Fort (2006) documents the details of many of the reforms. As mentioned in Fort (2006), the exact date that each reform began to affect the population is sometimes in dispute. Thus, I follow Meyer (2015) in using implementation dates that are consistent with Brunello et al. (2009) and Gathmann et al. (2015). These reforms increased the minimum education level by 1 to 4 years and affected individuals born between 1917 and 1969. The typical reform among this group moved the minimum leaving age up to the 9th or 10th grade. As previously mentioned, the key attribute of these reforms is that they provide plausibly exogenous variation in educational attainment. Individuals are compelled into the additional education rather than electing the extra education because of unobserved factors.

Table 1. Reforms.

\begin{tabular}{|c|c|c|c|c|}
\hline Country/region & Reform date & First cohort potentially affected & Change in min. schooling level & Source \\
\hline Austria & 1962 & 1947 & $8-9$ & $\mathrm{BR}, \mathrm{F}, \mathrm{GA}$ \\
\hline Belgium & 1983 & 1969 & $8-12$ & $B R, F$ \\
\hline Denmark & 1971 & 1957 & $7-9$ & $A R, B R, F, G A$ \\
\hline England and Wales & 1947 & 1933 & $8-9$ & $\mathrm{CR}, \mathrm{DH}, \mathrm{GA}, \mathrm{HW}, \mathrm{O}$ \\
\hline England and Wales & 1973 & 1958 & $9-10$ & $\mathrm{CR}, \mathrm{GA}, \mathrm{GR}, \mathrm{HW}$ \\
\hline France & 1937 & 1923 & $7-8$ & $A L, F, G A$ \\
\hline France & $1959 / 1967$ & 1953 & $8-10$ & $A L, B R, F, G A, G R$ \\
\hline Greece & 1975 & 1963 & $6-9$ & $B, F$ \\
\hline Ireland & 1972 & 1958 & $8-9$ & $\mathrm{BR}, \mathrm{CH}, \mathrm{GA}$ \\
\hline Italy & 1963 & 1949 & $5-9$ & $B C, B R, F, G A, D D$ \\
\hline
\end{tabular}




\begin{tabular}{|c|c|c|c|c|}
\hline Country/region & Reform date & First cohort potentially affected & Change in min. schooling level & Source \\
\hline Netherlands & 1928 & 1917 & $6-7$ & GA, vK \\
\hline Netherlands & 1950 & 1938 & $7-9$ & GA, L \\
\hline Netherlands & 1973 & 1959 & $9-10$ & $B R, F, G A, L$ \\
\hline Northern Ireland & 1957 & 1943 & $8-9$ & GA, F, O \\
\hline Scotland & 1946 & 1932 & $8-9$ & GA \\
\hline Scotland & 1976 & 1958 & $9-10$ & GA \\
\hline Spain & 1970 & 1957 & $6-8$ & $B R, F, G A, P$ \\
\hline Sweden & 1962 & 1950 & $8-9$ & $B R, F, H J, M$ \\
\hline \multicolumn{5}{|c|}{ 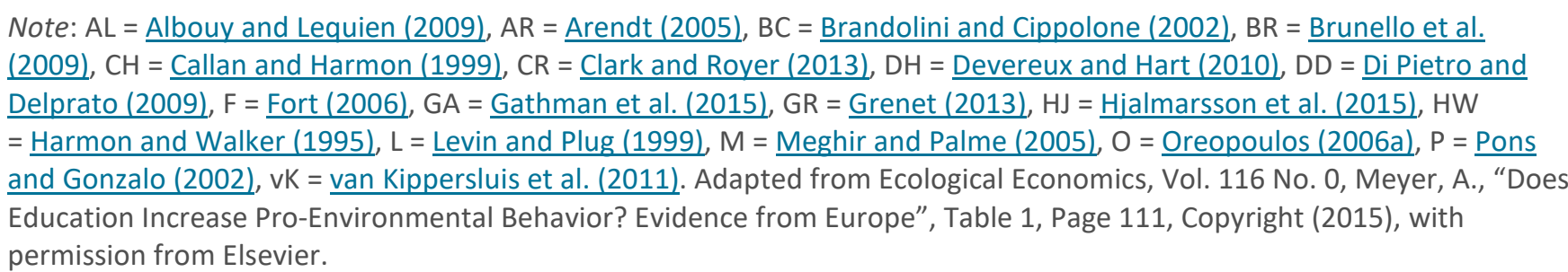 } \\
\hline
\end{tabular}

The analysis only includes individuals born close enough to a change in the corresponding education reform. Define the pivot cohort as the first cohort that was potentially affected by a change in compulsory education law $j$ and denote the birth year of the pivot cohort as $b_{j}$. Let $k=\left(b-b_{j}\right)$ indicate the number of years between the cohort from year $b$ and the pivot cohort. Clearly, I need to know when an individual was born to make this calculation. Some approximation is required here because only age, not birth year, is reported on the survey. As discussed in Meyer (2015), one can be fairly certain of the birth year from some survey waves. For example, Eurobarometer 68.2 was conducted in the months of November 2007-January 2008. Nearly all of the respondents would have had their birthday in calendar year 2007. It is less clear for other survey waves such as Eurobarometer 75.2 because it was conducted in the months of April-May 2011; there is a higher likelihood that an individual would not have had their birthday in calendar year 2011 at the time of the survey. Therefore, I code birth year as (year-age) for individuals in survey waves conducted between September and December and (year-age-1) for individuals in survey waves conducted between January and May. $\underline{8}$

To begin, individuals with $k \in[-10,-1]$ comprise the pre-reform sample and individuals with $k \in[1$, 10] make up the post-reform sample. 9 In this bandwidth of \pm 10 years, there are 109,238 observations from individuals who provide an answer to the question about educational attainment. I then narrow the sample to include only individuals who provide an answer to the left-right political ideology 
question, leaving 94,694 observations. The specific wording of the left-right political ideology question, which is identical in all waves of the survey, is as follows, "In political matters people talk of the 'the left' and 'the right'. How would you place your views on this scale?" Interviewers then showed the respondent a card with a 10 point scale, ranging from 1 (left) to 10 (right).

Table 2 shows the distribution of the answer to the left-right identity question for the 94,694 individuals who answer the question. In addition, I present a histogram to visualize the distribution in Fig. 1. The distribution is approximately symmetric with a clear spike corresponding to the answer of " 5 ". An answer of " 5 " likely indicates that an individual sees themselves as a centrist, not identifying with either the left or the right. Table 3 summarizes this variable by country; there are only modest differences in the averages across the sample countries. Table 4 provides summary statistics for each of the variables. The average age when leaving full-time education for the sample is approximately 18.5 , the sample is approximately $49 \%$ male, the average age is about 54 years, and the average response to the left-right ideology question is 5.18. Moreover, a little more than one-half of the individuals in the sample were affected by the educational reforms. The online appendix provides summary statistics by country. The biggest differences across countries are in age, which is determined by the date(s) of each country's reform(s), and in average age of leaving full-time education. For example, the average age of leaving full-time education in some countries such as Spain, Italy, and UK is less than 17 years whereas the average age of leaving education is as high as 21.38 in Denmark and 20.21 in Sweden.

Table 2. Summary of self-reported left-right placement.

\begin{tabular}{lll}
$\begin{array}{lll}\text { Left-right } \\
\text { placement }\end{array}$ & N & Percent \\
\hline Box 1-left & 3889 & 4.11 \\
\hline Box 2 & 4174 & 4.41 \\
\hline Box 3 & 11,479 & 12.12 \\
Box 4 & 12,614 & 13.32 \\
\hline Box 5 & 26,231 & 27.70 \\
\hline Box 6 & 12,252 & 12.94 \\
\hline Box 7 & 11,443 & 12.08 \\
\hline Box 8 & 7772 & 8.21 \\
Box 9 & 2016 & 2.13 \\
Box 10-right & 2824 & 2.98
\end{tabular}




\begin{tabular}{lll} 
Left-right & & \\
placement & N & Percent \\
\hline Total & 94,694 & 100 \\
\hline
\end{tabular}

Note: This summarizes the sample generated by a bandwidth of \pm 10 years.

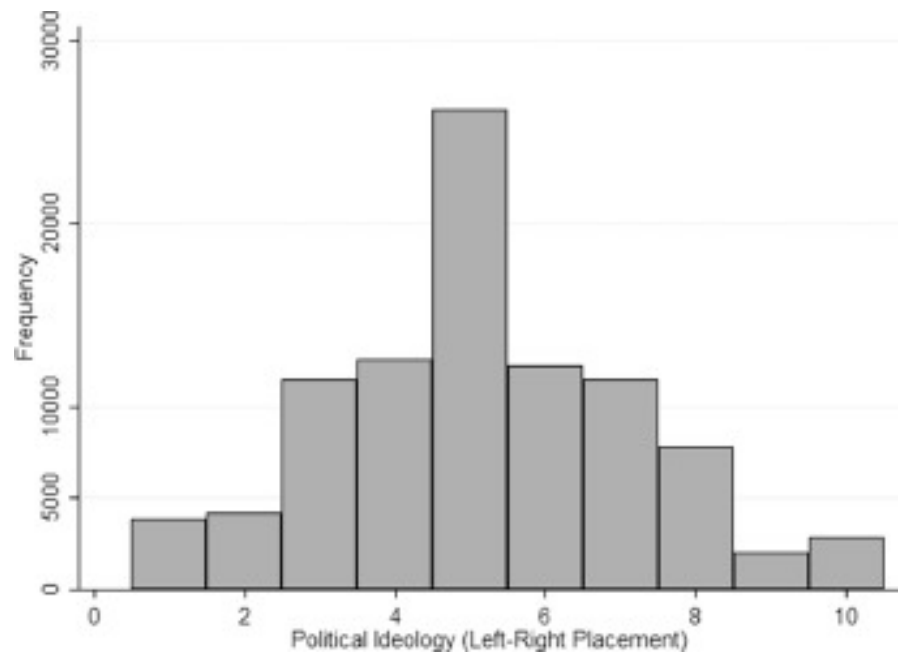

Fig. 1. Political ideology. Note: Histogram displays frequency of respondents' political ideology responses. $1=$ far left, 10 = far right.

Table 3. Left-right placement by country.

\begin{tabular}{llll} 
Country & N & Mean & Std. Dev. \\
\hline Austria & 6263 & 5.26 & 1.95 \\
Belgium & 7657 & 5.07 & 1.89 \\
Denmark & 7571 & 5.29 & 2.11 \\
Greece & 6392 & 5.40 & 2.16 \\
France & 9535 & 5.01 & 1.99 \\
Ireland & 6972 & 5.60 & 1.82 \\
Italy & 5045 & 5.18 & 2.43 \\
Netherlands & 17,337 & 5.06 & 1.97 \\
Spain & 5926 & 4.50 & 1.94 \\
Sweden & 8605 & 5.32 & 2.16 \\
United Kingdom & 13,391 & 5.30 & 1.84
\end{tabular}

Note: This summarizes the sample generated by a bandwidth of \pm 10 years. 
Table 4. Summary statistics.

\begin{tabular}{|c|c|c|c|c|c|}
\hline Variable & $\mathbf{N}$ & Mean & Std. Dev. & Min & Max \\
\hline \multicolumn{6}{|c|}{ Bandwidth of \pm 10 years } \\
\hline Education age & 94,694 & 18.50 & 3.84 & 0 & 25 \\
\hline Reform & 94,694 & 0.531 & 0.499 & 0 & 1 \\
\hline Male & 94,694 & 0.491 & 0.500 & 0 & 1 \\
\hline Age & 94,694 & 54.22 & 11.70 & 25 & 97 \\
\hline Left identity & 94,694 & 5.18 & 2.02 & 1 & 10 \\
\hline \multicolumn{6}{|l|}{ Bandwidth of \pm 7 years } \\
\hline Education age & 66,267 & 18.51 & 3.81 & 0 & 25 \\
\hline Reform & 66,267 & 0.521 & 0.500 & 0 & 1 \\
\hline Male & 66,267 & 0.489 & 0.500 & 0 & 1 \\
\hline Age & 66,267 & 54.43 & 11.21 & 28 & 97 \\
\hline Left right placement & 66,267 & 5.16 & 2.01 & 1 & 10 \\
\hline
\end{tabular}

\section{Empirical strategy}

The principal goal of this study is to estimate the impact of educational attainment on political ideology, as measured by left-right identity. In the experimental ideal, one would randomly assign individuals to different levels of education and then analyze differences in ideology across groups. However, absent such a randomized controlled trial, individuals will self-select into different levels of education and choose their political identity. Therefore, unobserved factors will likely impact both educational attainment and political ideology. As such, the primary empirical concern is omitted variables bias. I adopt an instrumental variables (IV) strategy to address endogeneity from the omitted variables. Changes in compulsory educational laws have become the instrument of choice for educational attainment in related research. Following this literature, I argue that changes in compulsory education laws are valid as an instrument because these changes exogenously compel individuals into higher educational attainment. That is, changes in these laws affect educational attainment but are uncorrelated with other unobservable factors that affect the outcome of interestin this case political ideology.

Previous research establishes the positive impact of this set of reforms on average educational attainment (Brunello et al., 2009; Brunello et al., 2013; Gathmann et al., 2015; Meyer, 2015). Nevertheless, it is useful to graphically present evidence of a discrete jump in educational attainment for the cohorts first affected by the reform in this particular sample. Recall that $k$ is the interval in 
number of years before or after the first affected cohort from each reform. Panels A and B of Fig. 2 plot average education versus $k$ for 10 years pre- and -post-reform. For Panel $A, I$ then regress education on $k$ and $k^{2}$ for two subsamples, once for the pre-reform period and once for the post-reform period. Finally, I plot the fitted values from these regressions to show the trends in educational attainment. Panel B of Fig. 2 shows the analogous graph for linear controls. Both panels of Fig. 2 show a discontinuity in average educational attainment in the year of the reform. Individuals born in the cohort immediately prior to a reform $(k=-1)$ are predicted to leave formal education 0.37 years earlier than individuals born in a cohort immediately following a reform $(k=1)$ in Panel A for quadratic controls. The size of the discontinuity for linear controls in Panel B is 0.26 years. I also show the analogous graphs using linear controls and bandwidths of 7 (Panel A) and 5 (Panel B) in Fig. 3 . From Fig. $\underline{3}$, it appears that a linear functional form fits the data rather well in these narrowed bandwidths.

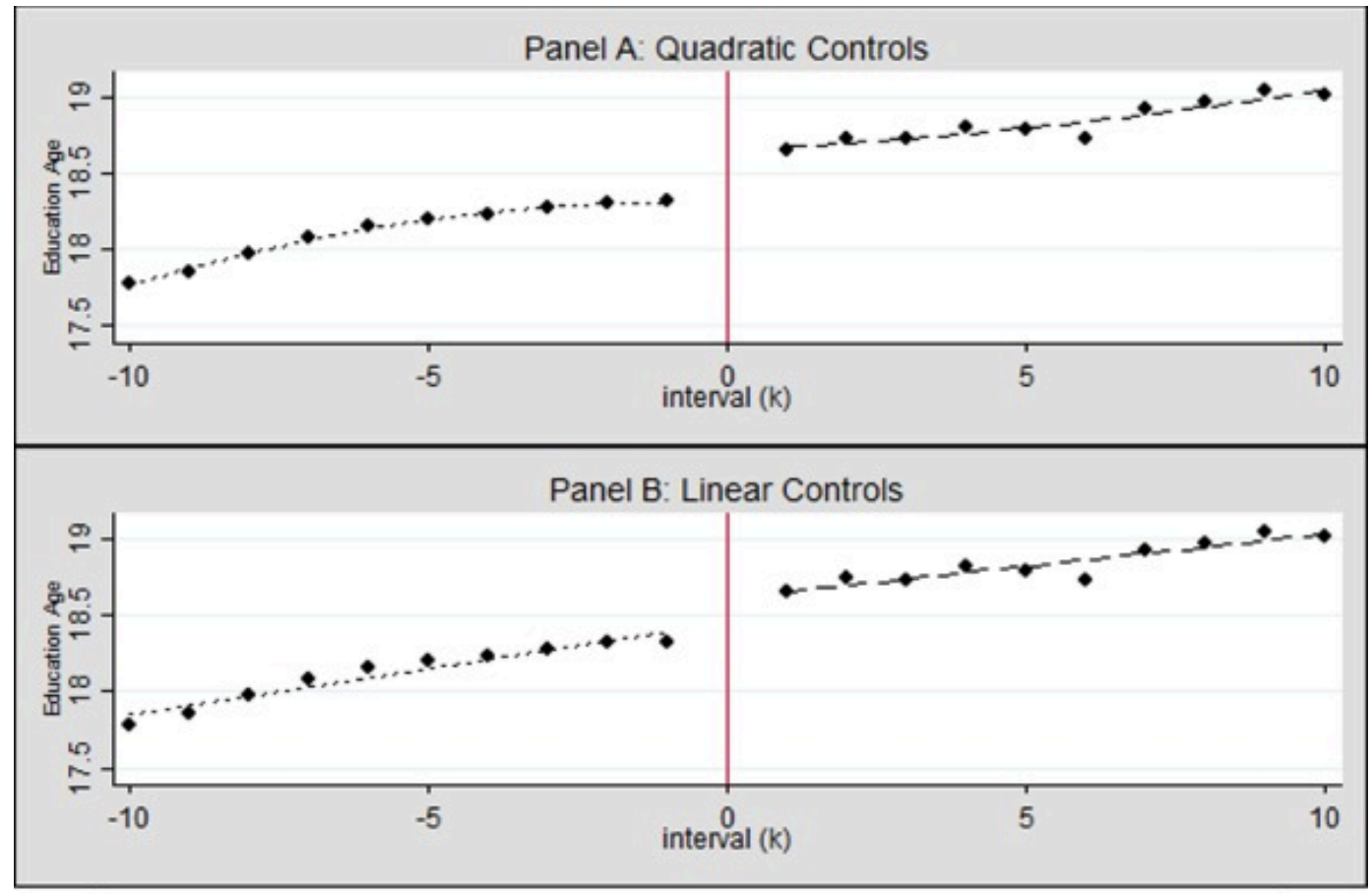

- Avg. Education Age $\quad . . . . . .$. Fitted values (pre-reform) - - - - Fitted values (post-reform)

Fig. 2. Education age vs. interval (k), bandwidth of 10. Note: Average education values represent means of all observations for a given interval (k). Fitted values are from separate regressions of education age on interval and interval squared (Panel A) and education age on interval (Panel B). The interval of 0 corresponds to the pivot cohort. Positive interval values correspond to individuals treated with educational reforms. 

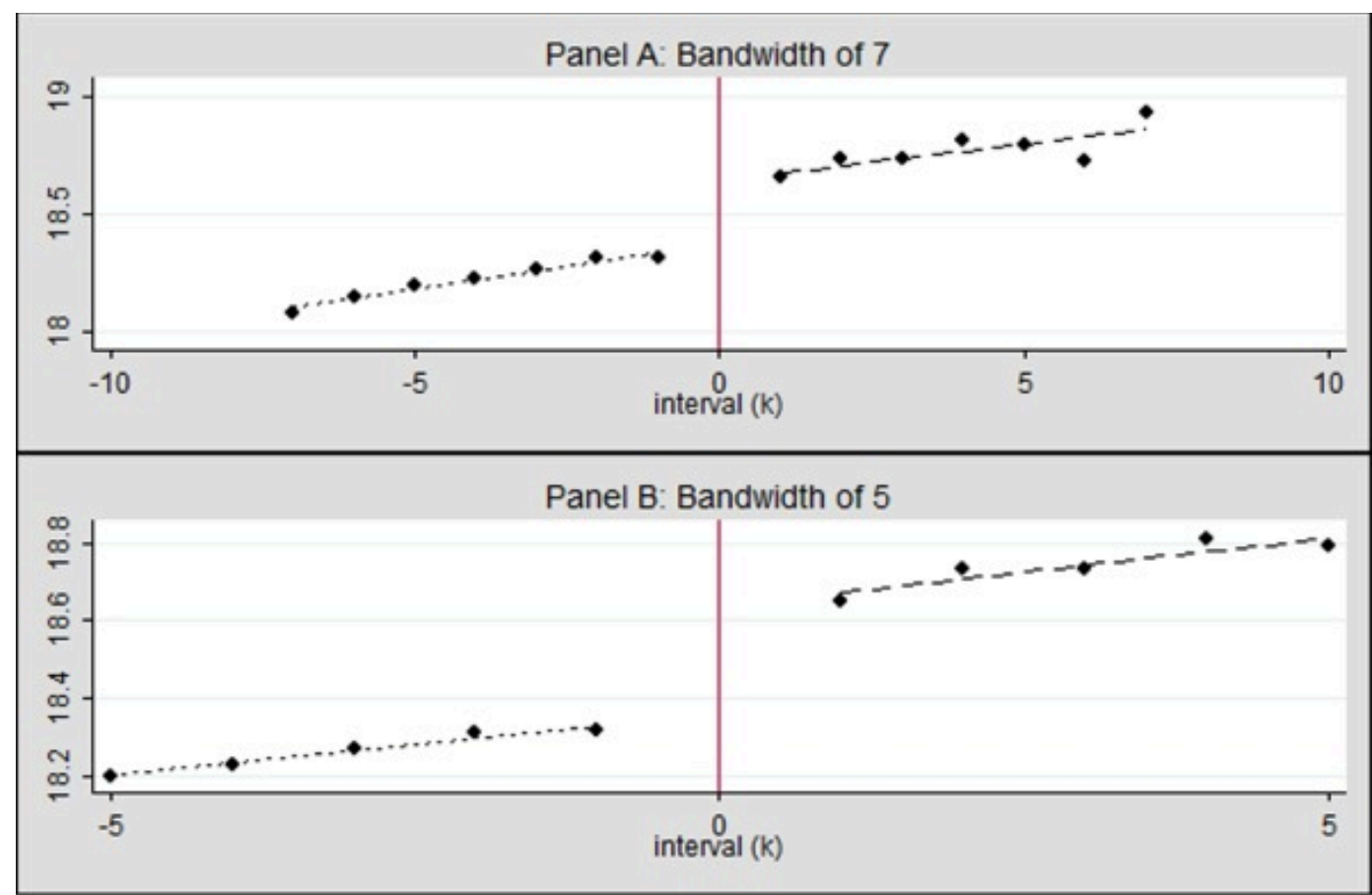

- Avg. Education Age …........ Fitted values (pre-reform) $\quad----$. Fitted values (post-reform)

Fig. 3. Education age vs. interval (k), narrowed bandwidths. Note: average education values represent means of all observations for a given interval (k). Fitted values are from separate regressions of education age on interval. The interval of 0 corresponds to the pivot cohort. Positive interval values correspond to individuals treated with educational reforms.

Following the approach utilized elsewhere in the literature, I utilize a fuzzy regression discontinuity design (RDD) to identify the effect of compulsory education reforms on political ideology. This leads to the following two-equation model specification for individual $i$ from reform $c$.

(1)

$$
\begin{aligned}
\text { ideology }_{i c}=\quad \beta_{0} & +\beta_{1} \text { education }_{i c}+f\left(k_{i c}\right)+\boldsymbol{X}_{i c}^{\prime} \beta_{2} \\
& + \text { ReformFE }+ \text { Survey } F+\mu_{i c}
\end{aligned}
$$

and

(2)

$$
\begin{aligned}
& \text { education }_{i c}=\alpha_{0}+\alpha_{1} R_{i c}+g\left(k_{i c}\right)+\boldsymbol{X}_{i c}^{\prime} \alpha_{2} \\
& + \text { ReformFE }+ \text { SurveyFE }+\epsilon_{i c} \text {. }
\end{aligned}
$$

Here, $f\left(k_{i c}\right)$ and $g\left(k_{i c}\right)$ are controls for cohort trends, $\boldsymbol{X}_{i c}^{\prime}$ is a vector of exogenous controls, $\underline{\underline{10}} R_{i c}$ is an indicator for being affected by the educational reform, ReformFE is a set of reform fixed effects, and SurveyFE is set of survey wave fixed effects. 
Identification of $\alpha_{1}$ in the RDD requires that the potentially endogenous relationship between birth cohort and educational attainment is captured by the controls, $g\left(k_{i c}\right)$. After controlling for these cohort trends, individuals on both sides of the pivot cohort should have the same average educational attainment within some range. A discontinuous jump in educational attainment at the pivot cohort can then be attributed to the reform. I allow the slope of the regression function to change at the pivot cohort by interacting the linear or quadratic controls with the reform indicator, $R_{i c}$. Therefore, with quadratic controls, 11 Eq. (2) becomes

(3)

$$
\begin{aligned}
\text { education }_{i c}= & \alpha_{0}+\alpha_{1} R_{i c}+\gamma_{1} k_{i c}+\gamma_{2}\left(R_{i c} * k_{i c}\right)+\gamma_{3} k_{i c}^{2} \\
& +\gamma_{4}\left(R_{i c} * k_{i c}^{2}\right)+X_{i c}^{\prime} \alpha_{2} \\
& + \text { ReformFE }+ \text { SurveyFE }+\epsilon_{i c} .
\end{aligned}
$$

Eq. (1) is then analogously modified to substitute the appropriate linear or quadratic controls for $f\left(k_{i c}\right)$, resulting in

$$
\begin{aligned}
\text { ideology }_{i c}= & \beta_{0}+\beta_{1} \text { education }_{i c}+\lambda_{1} k_{i c}+\lambda_{2}\left(R_{i c} * k_{i c}\right)+\lambda_{3} k_{i c}^{2} \\
& +\lambda_{4}\left(R_{i c} * k_{i c}^{2}\right)+\boldsymbol{X}_{i c}^{\prime} \beta_{2} \\
& + \text { ReformFE }+ \text { SurveyFE }+\mu_{i c}
\end{aligned}
$$

for the case of quadratic controls. ${ }^{12}$ Furthermore, I interact the linear/quadratic controls in Eqs. (3) and (4) with a set of reform dummies so that each reform can take on its own trend. $\underline{13}$

I initially set the bandwidth at \pm 10 years, which produces the maximum sample size with no individual being counted as part of both the pre- and -post-reform groups. This also corresponds to the window chosen by Gathmann et al. (2015). I then decrease the bandwidth to \pm 7 years as a specification check. A 7 year bandwidth substantially cuts the sample size but matches the window chosen by Brunello et al. (2009). The tradeoff is that wider bandwidths provide more power but may increase the probability that the included controls do not adequately capture cohort trends. Moreover, I report results for all other possible bandwidths of 2-6 and 8-9 years.

As previously mentioned, I exclude individuals from the pivot cohort because I cannot reliably determine whether or not they were treated with the reform. Therefore, I am effectively utilizing a "donut-hole" RD estimator. 14 Previous studies have shown that this strategy can be advantageous for reasons beyond measurement error. One typical issue in RD estimation is the possibility of manipulation of the forcing variable (Lee \& Lemieux, 2010; McCrary, 2008); the "donut-hole" approach can be useful if one suspects such manipulation. For example, Barreca, Guldi, Lindo and Waddell 
(2011) revisit the conclusions of Almond, Doyle, Kowalski, and Williams (2010) regarding the reduction in 1-year infant mortality as birth weight crosses the $1500 \mathrm{~g}$ "very-low-birth-weight (VLBW)" threshold. Barreca et al. (2011) note that the observations occurring at this important threshold are systematically different from those on either side of the threshold so including these threshold observations can bias results. Furthermore, the authors argue that RD estimates should not be sensitive to the observations at the threshold so it can be useful to remove a "donut-hole" of observations (Barreca et al., 2011). Due to merging 25 different waves of surveys with inconsistent demographic questions, I do not have the ability to test for differences in observable characteristics from individuals in different birth cohorts. In the present context, therefore, one advantage of the donut-hole RD is that it allows for the possibility that individuals born in the pivot cohort are systematically different from the surrounding cohorts. .15

Consistent with previous studies in this literature (Brunello et al., 2009; Gathmann et al., 2015; Grenet, 2013; Meyer, 2015), I view these as parametric regression specifications. This implicitly assumes that we know the functional form. Many recent RDD papers instead use nonparametric local polynomial regression, which is more appropriate if we are treating the functional form as unknown. Therefore, I also report results using local linear specifications of the fuzzy RDD instead of the parametric global polynomial approach. I utilize a triangular kernel to weight observations and a local quadratic polynomial for bias correction. I select the bandwidth in two ways; I first use the cross-validation procedure from Ludwig and Miller (2007) and then use the Imbens and Kalyanaraman (2012) approach. In each case, I present conventional and bias corrected point estimates along with conventional and robust (Calonico, Cattaneo, \& Titiunik, 2014a) standard errors. 16

\section{Results and discussion}

\subsection{Main results}

To begin, columns 1 and 2 of Table 5 present 2SLS results from the bandwidths of \pm 10 years from a pivot cohort. Column 1 uses linear controls while column 2 uses quadratic controls. Error terms may possibly be correlated between individuals from the same reform group and birth cohort. As such, I cluster standard errors at the birth year-reform level.17 I do find a statistically significant local average treatment effect (LATE) of educational attainment on left-right ideology. An additional year of educational attainment leads to an approximate 0.25 point movement to the right on the 10 point scale. Relative to the sample mean of political affiliation, this represents an approximate $5 \%$ movement to the right. 
Table 5. 2SLS regression results.

$\begin{array}{llll}(1) & (2) & (3) & (4) \\ 2 S L S & 2 S L S & 2 S L S & 2 S L S\end{array}$

2nd stage. Outcome is left-right affiliation. $1=$ far left, $5=$ center, $10=$ far right

$\begin{array}{lllll}\text { Education age } & 0.256^{* *} & 0.235^{* *} & 0.249^{* *} & 0.269_{-}^{*} \\ & (0.120) & (0.116) & (0.107) & (0.157) \\ \text { Male } & 0.0466 & 0.0533 & 0.0549 & 0.0491 \\ & (0.0460) & (0.0445) & (0.0459) & (0.0578) \\ \text { Age } & 0.0332 & 0.0336 & 0.0526 & 0.0582 \\ & (0.0273) & (0.0267) & (0.0321) & (0.0408) \\ \text { Age }^{2} & -0.000357 & -0.000361 & -0.000483_{-}^{*} & -0.000534 \\ & (0.000228) & (0.000225) & (0.000264) & (0.000345)\end{array}$

1st stage. Outcome is education age.

\begin{tabular}{|c|c|c|c|c|}
\hline \multirow[t]{2}{*}{ Reform } & $0.253^{* * *}$ & $0.372^{* * *}$ & $0.316^{* * *}$ & $0.332^{* * *}$ \\
\hline & $(0.0487)$ & $(0.0841)$ & $(0.0603)$ & (0.111) \\
\hline \multirow[t]{2}{*}{ Male } & $0.323^{\cdots *}$ & $0.323^{* * *}$ & $0.322^{* * *}$ & $0.323^{* * *}$ \\
\hline & $(0.0224)$ & $(0.0224)$ & $(0.0266)$ & $(0.0267)$ \\
\hline \multirow[t]{2}{*}{ Age } & $-0.168^{* * *}$ & $-0.176^{* * *}$ & $-0.232^{* * *}$ & $-0.232^{* * *}$ \\
\hline & $(0.0248)$ & $(0.0250)$ & $(0.0309)$ & $(0.0310)$ \\
\hline \multirow[t]{2}{*}{ Age $^{2}$} & $0.00145^{* * *}$ & $0.00151^{* * *}$ & $0.00195^{* * *}$ & $0.00195^{* * *}$ \\
\hline & $(0.000207)$ & $(0.000209)$ & $(0.000258)$ & $(0.000259)$ \\
\hline F-Stat & 310.85 & 216.94 & 219.13 & 152.66 \\
\hline ( $p$-value) & $<0.0001$ & $<0.0001$ & $<0.0001$ & $<0.0001$ \\
\hline F-Stat on excluded instrument & 24.02 & 24.00 & 28.11 & 12.77 \\
\hline ( $p$-value) & $<0.0001$ & $<0.0001$ & $<0.0001$ & 0.0004 \\
\hline Bandwidth & \pm 10 & \pm 10 & \pm 7 & \pm 7 \\
\hline Cohort trends & Linear & Quadratic & Linear & Quadratic \\
\hline $\mathbf{N}$ & 94,694 & 94,694 & 66,267 & 66,267 \\
\hline
\end{tabular}

Robust standard errors in parentheses are clustered at the birth year-reform level.

All regressions include cohort trends that can vary at the reform level, reform fixed effects, and survey wave fixed effects.

$* * * p<0.01$ 
${ }^{* *} p<0.05$,

$*_{p}<0.1$.

As a specification check, I next decrease the bandwidth to \pm 7 years in columns 3 and 4 of Table 5 . The estimated effects of education on political ideology are rather similar to their counterparts in columns 1 and 2. I also show abbreviated results for bandwidths of 2-6 and 8-9 years in Table 6 for the case of linear cohort trends. As seen in Table 6, an extra year of education leads to a movement to the right of 0.22-0.47 across the various bandwidths, with most of the point estimates concentrated around 0.25.

Table 6. 2SLS regression results, alternative bandwidths.
(1)
(2)
(3)
(4) (5)
(6) (7)

Bandwidth

$\pm 9 \quad \pm 8$

$\pm 6 \quad \pm 5$

$\pm 4$

$\pm 3 \quad \pm 2$

2nd stage. Outcome is left-right affiliation. 1 = far left, 5 = center, 10 = far right

$\begin{array}{lllllllll}\text { Education age } & 0.241_{-*}^{* *} & 0.220^{* *} & 0.224_{-}^{* *} & 0.258^{* *} & 0.331_{-}^{*} & 0.282_{-}^{*} & 0.470^{* *} \\ & (0.112) & (0.111) & (0.0967) & (0.120) & (0.174) & (0.149) & (0.237)\end{array}$

1st stage. Outcome is education age.

\begin{tabular}{llllllll} 
Reform & $0.270^{* * *}$ & $0.293^{* * *}$ & $0.357^{* * *}$ & $0.306^{* * *}$ & $0.257^{* * *}$ & $0.326^{* * *}$ & $0.260_{-}^{*}$ \\
& $(0.0519)$ & $(0.0555)$ & $(0.0662)$ & $(0.0743)$ & $(0.0867)$ & $(0.107)$ & $(0.158)$ \\
\multirow{2}{*}{ F-Stat on excluded instrument } & 24.54 & 26.17 & 33.61 & 20.86 & 11.30 & 13.65 & 10.80 \\
(p-value) & $<0.0001$ & $<0.0001$ & $<0.0001$ & $<0.0001$ & 0.001 & 0.0003 & 0.0016 \\
N & 85,344 & 76,056 & 56,842 & 47,212 & 37,558 & 28,195 & 18,647
\end{tabular}

Robust standard errors in parentheses are clustered at the birth year-reform level.

All regressions include gender controls, a quadratic of age, linear cohort trends that can vary at the reform level, reform fixed effects, and survey wave fixed effects.

$* * * p<0.01$,

$*^{* *} p<0.05$,

$*_{p}<0.1$

When using 2SLS one may be concerned about the possibility of weak instruments. Therefore, I present first stage regression results in $\underline{\text { Tables } 5}$ and $\underline{6}$. The first stage results from all specifications show that the educational reform does have a statistically significant positive effect. Moreover, the Fstats are all above the rule of thumb value of 10 (Stock, Wright, \& Yogo, 2002). Furthermore, the magnitude of the first stage effect is in line with previous studies. Using many of the same reforms, Gathmann et al. (2015)report a first stage of 0.501 (men)/0.541 women and Brunello et al. (2009)show an average first stage of around 0.3. With a slightly different set of reforms, Borgonovi et al. (2010) report a first stage of 0.508 . 
All results presented thus far have attempted to deal with the endogeneity of education. However, it is illustrative to examine the results when treating education as exogenous. Thus, Table 7 shows OLS results from 4 representative bandwidths. As seen across the columns of Table 7 , there is a statistically significant association between educational attainment and left-leaning ideology when treating education as exogenous. This could suggest that unobservable characteristics tend to move individuals toward a left political ideology as educational attainment increases. Alternatively, it could be that the subgroup of compliers-those who take up treatment from the instrument-is different from the general population. In the context of these compulsory educational reforms, the compliers are likely located in the lower end of the educational attainment distribution. Thus, one should interpret the findings in this paper as representing the effect of education on political identity at the lower end of the educational distribution and for these particular reforms.

Table 7. Exogenous education regression results: OLS.
(1)
(2)
(2)
(3)

Bandwidth

Education age $-0.0149 * * *$ (0.00347)

Male $0.136^{* * *}$ (0.0181)

N 94,694 $\pm 5$ $\pm 2$

$-0.0163^{* * *}-0.0189^{* * *}-0.0223^{* * *}$

$\begin{array}{lll}(0.00408) & (0.00468) & (0.00698)\end{array}$

$0.142^{* * *} \quad 0.137 * 0.130 * * *$

$(0.0217) \quad(0.0260) \quad(0.0404)$

$66,267 \quad 47,212 \quad 18,647$

Robust standard errors in parentheses are clustered at the birth year-reform level. All regressions include a quadratic of age, reform fixed effects, and survey wave fixed effects.

$* * * p<0.01$,

\subsection{Ordered probit results}

The results presented so far treat the left-right affiliation as a continuous variable and assume a constant marginal effect of education on political affiliation. This is likely a fine approximation but I also address this issue by estimating two ordered probit specifications that use all available observations and treat educational attainment as endogenous. The ordered probit model utilizes Eqs. (3) and (4), but substitutes a latent index in place of the continuous left-hand side variable in Eq. (4). .18 IV ordered probit specification 1 (IVOP1) codes the dependent variable into 3 categories (original responses of 1 through $4=$ " 1 ", $5=$ "2", 6 through $10=$ " 3 "). IV ordered probit specification 2 (IVOP2) codes the dependent variable into 5 categories (original responses of 1 or $2=$ " 1 ", 3 or $4=$ " 2 ", $5=$ " 3 ", 6 or $7=$ " 4 ", 8 through $10=$ " 5 "). The main drawback of the ordered probit model is that interpretation is more complicated. In interpreting the impact of educational attainment on political identity, there are as 
many marginal effects as categories of the dependent variable. IVOP1 has the simpler interpretation as the categories correspond to "left," "center," and "right." IVOP2 is more flexible and attempts to group the values of the dependent variable according to the patterns visible in Fig. 1.

Table 8 presents maximum likelihood results from the two ordered probit specifications for linear controls and a bandwidth of \pm 7 years. As seen in $\underline{\text { Table } 8}$, the ordered probit results are consistent with the baseline 2SLS results. The positive signs on the coefficients on education across the columns indicate that, when accounting for the endogeneity of education, additional educational attainment moves individuals to the right of the political scale. However, one must examine the average marginal effects to infer the magnitude of the change. The interpretation of the marginal effects is most straightforward in column 1 from IVOP1 so I concentrate on those but note that the results in column 2 from IVOP2 tell a similar story. Results in column 1 suggest that an extra year of educational attainment decreases the probability of falling into the left category (1-4) by approximately 4 percentage points and increases the probability of falling into the right category (6-10) by a similar magnitude. There is a statistically significant decrease in the probability of falling into the center category (5) with more education; however, this effect has near 0 magnitude. Therefore, overall, the results from Table 8support the baseline analysis in showing that additional educational attainment moves individuals to the right.

Table 8. IV ordered probit regression results.

\section{(1) (2)}

\begin{tabular}{lll} 
Variables & MLE (IVOP1) & MLE (IVOP2) \\
\hline Education age & $0.121^{* * *}$ & $0.103^{* *}$ \\
& $(0.0442)$ & $(0.0437)$
\end{tabular}

\section{Cutpoints}

$\begin{array}{lll}\text { Cut1 } & 3.95_{-*}^{* *} & 2.24 \\ & (1.79) & (1.91) \\ \text { Cut2 } & 4.60 * * & 3.14_{-}^{*} \\ & (1.76) & (1.87) \\ \text { Cut3 } & & 3.82^{* *} \\ & & (1.84\end{array}$

Cut4 4.58** 
(1) (2)

Variables MLE (IVOP1) MLE (IVOP2)

Average ME of education

Left (1-4) $\quad-0.0416^{* * *}$

(0.0140)

Far Left (1-2) - $\quad-0.0184_{-}^{*}$

(0.00989)

Center Left (3-4) - $\quad-0.0175 *$

(0.00445)

Center (5) $\quad-0.00108^{* * *} \quad-0.00106 *$

(0.00011) (0.00017)

Center Right (6-7) $0.0134^{* * *}$

(0.00301)

Far Right (8-10) $0.0236^{* *}$

(0.0115)

Right (6-10) $\quad 0.0427^{* * *}$

(0.0140)

Robust standard errors in parentheses are clustered at the birth year-reform level.

All regressions include gender controls, a quadratic of age, linear cohort trends that can vary at the reform level, reform fixed effects, and survey wave fixed effects. $N=66,267$. The bandwidth is \pm 7 years.

Average ME's of education are calculated using Stata's margins command.

$* * * p<0.01$,

$* * p<0.05$

$* p<0.1$

\subsection{Discussion of theories and country-specific results}

The developmental thesis predicts that education will move individuals to a more liberal ideology and is hence not supported by the results presented in the preceding sections. In contrast, according to the self-interest thesis, individuals will move to the right out of self-interest when their incomes increase. Previous research establishes that many of these reforms increased earnings for the compliers.

However, other papers find small or no effects on earnings. Appendix Table A1 summarizes previous studies of the compulsory education reforms utilized in this paper and shows that there is strongest prior evidence of significant earnings increases for the UK reforms and some evidence of earnings increases for Italy and Netherlands. Thus, if the self-interest thesis is correct, we should see more movement to the political right in these countries. Likewise, we should not see significant movement 
to the right in countries such as France or Sweden where the reforms have not been shown to significantly affect earnings. Hence, instead of pooling together all the reforms and running one analysis, I estimate the model on each of the countries separately. Table 9 shows the LATE of education on political ideology by country. To probe the stability of the results, I present 4 bandwidths for each country. The sample size drastically decreases when examining one country at a time which cuts statistical power, but the point estimates are informative. The second stage point estimates are consistently positive for 3 of the 11 countries (Italy, Netherlands, and UK), consistently negative for 1 country (Spain), and sometimes positive/sometimes negative for 7 of the countries (Austria, Belgium, Denmark, France, Greece, Ireland, and Sweden). However, the standard errors are large for most of these estimates so I typically cannot reject the null of 0 effect at conventional levels. In support of the self-interest thesis, I find some evidence that the Italian reform moved individuals to the right and no evidence that the French reforms affected political ideology. I also find weak evidence that the UK reforms may have moved individuals to the right, but the estimates are never significant at conventional levels. There is some evidence that the Swedish reform moved individuals to the right but the result does not appear robust to the bandwidth selection. As seen in Table A1, Meghir and Palme $\underline{(2005)}$ find little evidence that this reform increased earnings, with a small positive point estimate. Therefore, overall, the country-specific results are consistent with the predictions of the self-interest thesis.

Table 9. Regression results by country.

$\begin{array}{llllll}\text { Country/region } & \mathbf{N} & \text { Bandwidth } & \begin{array}{l}\text { 2nd stage effect of } \\ \text { education on political } \\ \text { ideology }\end{array} & \begin{array}{l}\text { 1st stage effect of } \\ \text { reform on education }\end{array} & \begin{array}{l}\text { 1st stage } \text { F-Stat on } \\ \text { excluded instrument }\end{array} \\ \text { Austria } & 4403 & 7 & -1.92(3.84) & -0.105(0.200) & 0.279 \\ \text { Austria } & 6263 & 10 & -0.647(0.514) & -0.296_{-}^{*}(0.161) & 3.39 \\ \text { Austria } & 5690 & 9 & -0.485(0.461) & -0.311_{-}^{*}(0.170) & 3.33 \\ \text { Austria } & 3774 & 6 & 0.0496(0.183) & -0.00241(0.219) & 0.000122 \\ \text { Belgium } & 5380 & 7 & 0.230(0.572) & 0.212(0.162) & 1.71 \\ \text { Belgium } & 7657 & 10 & 0.0269(0.338) & 0.277_{-}^{* *}(0.131) & 4.50 \\ \text { Belgium } & 6930 & 9 & 0.0328(0.408) & 0.242_{-}^{*}(0.139) & 3.04 \\ \text { Belgium } & 4641 & 6 & -0.102(0.476) & 0.266(0.177) & 2.25 \\ \text { Denmark } & 5093 & 7 & -0.197(0.564) & 0.250(0.285) & 0.771 \\ \text { Denmark } & 7571 & 10 & 0.474(0.628) & 0.248(0.224) & 1.22 \\ \text { Denmark } & 6718 & 9 & 0.244(0.421) & 0.313(0.242) & 1.68\end{array}$




\begin{tabular}{|c|c|c|c|c|c|}
\hline Country/region & $\mathbf{N}$ & Bandwidth & $\begin{array}{l}\text { 2nd stage effect of } \\
\text { education on political } \\
\text { ideology }\end{array}$ & $\begin{array}{l}\text { 1st stage effect of } \\
\text { reform on education }\end{array}$ & $\begin{array}{l}\text { 1st stage } F \text {-Stat on } \\
\text { excluded instrument }\end{array}$ \\
\hline Denmark & 4339 & 6 & $-0.137(0.364)$ & $0.414(0.314)$ & 1.74 \\
\hline France & 6748 & 7 & $0.0357(0.227)$ & $0.474^{* *}(0.189)$ & 6.32 \\
\hline France & 9535 & 10 & $-0.277(0.324)$ & $0.297^{* *}(0.153)$ & 3.78 \\
\hline France & 8570 & 9 & $-0.104(0.227)$ & $0.414 * * *(0.163)$ & 6.46 \\
\hline France & 5746 & 6 & $-0.000035(0.201)$ & $0.585^{* * *}(0.207)$ & 8.03 \\
\hline Greece & 4628 & 7 & $0.700(0.652)$ & $0.357(0.246)$ & 2.12 \\
\hline Greece & 6392 & 10 & $-0.0531(0.371)$ & $0.307(0.201)$ & 2.35 \\
\hline Greece & 5833 & 9 & $0.205(0.437)$ & $0.305(0.213)$ & 2.04 \\
\hline Greece & 3965 & 6 & 0.855 (1.18) & $0.246(0.270)$ & 0.829 \\
\hline Ireland & 4803 & 7 & $-0.152(1.61)$ & $-0.0739(0.162)$ & 0.208 \\
\hline Ireland & 6972 & 10 & $-0.358(0.958)$ & $-0.109(0.132)$ & 0.687 \\
\hline Ireland & 6287 & 9 & $-0.0284(1.02)$ & $-0.0975(0.140)$ & 0.486 \\
\hline Ireland & 4087 & 6 & $0.905(3.21)$ & $-0.0652(0.182)$ & 0.128 \\
\hline Italy & 3532 & 7 & $0.339(0.220)$ & $0.911^{* * *}(0.306)$ & 8.85 \\
\hline Italy & 5045 & 10 & $0.339 *(0.196)$ & $0.836^{* * * *}(0.248)$ & 11.37 \\
\hline Italy & 4538 & 9 & $0.304 *(0.178)$ & $0.953^{* * *}(0.263)$ & 13.10 \\
\hline Italy & 3071 & 6 & $0.358^{* *}(0.172)$ & $1.31^{* * *}(0.339)$ & 14.80 \\
\hline Netherlands & 11,912 & 7 & $0.540(0.413)$ & $0.286^{* *}(0.142)$ & 4.04 \\
\hline Netherlands & 17,337 & 10 & $1.58(1.53)$ & $0.131(0.115)$ & 1.30 \\
\hline Netherlands & 15,562 & 9 & $0.994(0.861)$ & $0.171(0.122)$ & 1.95 \\
\hline Netherlands & 10,207 & 6 & $0.615(0.542)$ & $0.256 *(0.157)$ & 2.66 \\
\hline Spain & 4067 & 7 & $-0.993(1.30)$ & $0.239(0.288)$ & 0.691 \\
\hline Spain & 5926 & 10 & $-0.871(2.27)$ & $0.101(0.231)$ & 0.190 \\
\hline Spain & 5316 & 9 & $-0.381(25.33)$ & $0.0376(0.249)$ & 0.0227 \\
\hline Spain & 3451 & 6 & $-4.93(38.1)$ & $0.0413(0.320)$ & 0.0167 \\
\hline Sweden & 6192 & 7 & $0.316(0.255)$ & $0.542^{* * *}(0.212)$ & 6.50 \\
\hline Sweden & 8605 & 10 & $-0.150(0.181)$ & $0.581^{* * *}(0.173)$ & 11.24 \\
\hline Sweden & 7835 & 9 & $0.0481(0.181)$ & $0.588^{* * * *}(0.184)$ & 10.18 \\
\hline Sweden & 5339 & 6 & $0.488 *(0.288)$ & $0.601^{* * *}(0.233)$ & 6.68 \\
\hline
\end{tabular}




\begin{tabular}{|c|c|c|c|c|c|}
\hline Country/region & $\mathbf{N}$ & Bandwidth & $\begin{array}{l}\text { 2nd stage effect of } \\
\text { education on political } \\
\text { ideology }\end{array}$ & $\begin{array}{l}\text { 1st stage effect of } \\
\text { reform on education }\end{array}$ & $\begin{array}{l}\text { 1st stage F-Stat on } \\
\text { excluded instrument }\end{array}$ \\
\hline UK & 9509 & 7 & $0.0906(0.237)$ & $0.355^{* * *}(0.123)$ & 8.37 \\
\hline UK & 13,391 & 10 & $0.311(0.256)$ & $0.290^{* * *}(0.0993)$ & 8.54 \\
\hline UK & 12,085 & 9 & $0.249(0.257)$ & $0.298 * * *(0.106)$ & 7.93 \\
\hline UK & 8222 & 6 & $0.0414(0.239)$ & $0.383^{* * *}(0.133)$ & 8.26 \\
\hline \multicolumn{6}{|c|}{$\begin{array}{l}\text { Heteroskedastic robust standard errors are in parentheses. } \\
\text { Linear cohort trends, gender, and a quadratic of age are included. } \\
*_{* *}<<0.01 \\
*_{p} p<0.05 \\
*_{p}<0.1\end{array}$} \\
\hline
\end{tabular}

Under the socialization thesis, individuals affected by the educational reforms simply learn more about the core values of their society. To the extent that the educational system explicitly or implicitly taught core values associated with a right-wing status, an additional year of education could push the individuals in that direction. I do not have information about how the explicit curricula may have differed across the different countries but there are ways to group countries by core values. One leading typology relies on classifying the welfare regime. Esping-Anderson $(1990,1999)$ divides European countries into three welfare regimes: liberal, conservative, and social democratic.19Liberal countries include Ireland and the UK. Social democratic countries include Denmark and Sweden. Conservative countries include Austria, France, Greece, Italy, Netherlands, and Spain. Again referring to the country-specific results in Table 9, I find evidence that both supports and conflicts with the socialization thesis. Second stage results are strongest for Italy, where it appears that more education moves individuals to the political right. This is supportive of the socialization thesis because Italy is classified as a conservative country. However, Sweden is classified as a social democratic country so the weak positive and significant result disagrees with the socialization thesis. The other two countries with consistently positive point estimates across the bandwidths, Netherlands and UK, fall respectively into Esping-Anderson's conservative and liberal (neo-liberal, laissez-faire) groupings, which appears consistent with the socialization thesis. However, the results that agree with the socialization thesis under Esping-Anderson's classification only happen in instances where the results also agree with the self-interest thesis.

I use one more metric to gauge the dominant core values of each country. For each country, I take the average of the left-right placement value for individuals who were 21 years or older when stopping full-time education. Recall that the compulsory education reforms primarily affected individuals in the lower end of the education distribution so this measure would reflect the left-right ideology of the 
peers who were not affected. Appendix Table A2 summarizes these averages by country and shows that the most left-leaning countries for this sample are Spain, France, and Netherlands. The most rightleaning countries are Austria, Denmark, Ireland, Italy, and Sweden. Belgium, Greece, and UK fall in between the others. Appendix Table A3 shows 2 SLS results on these groupings of countries. I find no effect of education on political ideology when limiting the sample to the left-leaning countries in column 1 but the first stage is somewhat weak. Moreover, the effect does seem strongest in the rightleaning countries ( 0.390 in column 2 ). This LATE for right-leaning countries is approximately $57 \%$ larger than the overall LATE in Table 5 but it is also less precisely estimated with a borderline weak first stage. Column 5 of Table A3 shows a LATE of 0.344 when excluding the left-leaning countries of Spain, France, and Netherlands and column 4 of Table A3shows a statistically insignificant LATE of 0.173 when excluding the right-leaning countries of Austria, Denmark, Ireland, Italy, and Sweden. Thus, I find no evidence that education moves individuals to the left for left-leaning countries. This suggests that the socialization thesis is not very potent but societal values may either dampen or intensify any selfinterested movement to the right.

It is also informative to examine the first stage estimates of the effect of an educational reform on years of education by country. As seen in Table 9 , several of the countries display little evidence of reforms increasing educational attainment. Three such countries (Austria, Ireland, and Spain) produce negative second stage point estimates for most of the bandwidths. Previous studies also find the reforms in Spain (Pons and Gonzalo, 2002) and Ireland (Callan and Harmon, 1999) to be rather ineffective in increasing average educational attainment, and hence weak instruments. Across the countries, I find first stage effects that are mostly in line with previous studies. I find a first stage effect for the UK reforms (0.290-0.383) in Table 9 that is consistent with previous studies from Table A1. The first stage effect is comparatively high for France for shorter bandwidths, but comparable to previous studies for the bandwidth of 10. I estimate a first stage effect for Italy that is considerably higher than the effect found in Brandolini and Cippolone (2002) but lower than the first stage effect from Di Pietro and Delprato (2009). Likewise, the first stage effect in Table 9 for Netherlands falls between those found by Levin and Plug (1999) and van Kippersluis et al. (2011). For Denmark, the first stage in Table $\underline{9}$ is similar to that found by Arendt (2005). Finally, I estimate a first stage effect for Sweden that is somewhat higher than that found by Meghir and Palme (2005). However, Meghir and Palme (2005)have a more refined regional educational reform measure which could explain some of the difference. 20 Supporting this notion, the first stage effects from Hjalmarsson et al. (2015) when not including municipality fixed effects are similar to what I find in $\underline{\text { Table } 9}$ but similar to Meghir and Palme (2005) when including the municipality effects. 


\subsection{Robustness checks}

Here, I conduct a series of robustness checks. In each case, I set the bandwidth at \pm 7 years and utilize linear cohort controls. 21 First, I exclude the countries that have the weakest or negative first stage effects of the reforms on educational attainment (Austria, Ireland, and Spain). As seen in column 1 of Table 10, the second stage estimated LATE increases only slightly and becomes more precise. In Column 2, I restrict the sample further to countries that have the strongest evidence of the reforms increasing educational attainment (France, Italy, Sweden, and UK). The second stage estimated LATE decreases to approximately 0.19 ( $3.7 \%$ of the sample mean) but remains significant at the $5 \%$ level. Next, recall that I exclude individuals from the pivot cohorts in the baseline analysis. Column 3 of Table 10 shows results when I include individuals from the pivot cohorts. As would be expected, the magnitude of the first stage decreases somewhat here because some individuals who were not actually treated with the reform are being coded as though they were treated. Nonetheless, the impact of education on political affiliation remains significant at the $10 \%$ level. In column 4 of Table 10, rather than allowing each reform to take on its own trend, I estimate the model with a common trend. Again, there is only a slight change to the point estimates and the second stage estimate remains significant at the $10 \%$ level.

Table 10. 2SLS regression results, robustness.

$\begin{array}{llllllll}\text { (1) } & \text { (2) } & \text { (3) } & \text { (4) } & \text { (5) } & \text { (6) } & \text { (7) } & \text { (8) } \\ \begin{array}{l}\text { Selected } \\ \text { countries }\end{array} & \begin{array}{l}\text { Selected } \\ \text { countries }\end{array} & \begin{array}{l}\text { Include } \\ \text { pivot } \\ \text { cohort }\end{array} & \begin{array}{l}\text { Common } \\ \text { Trend }\end{array} & \begin{array}{l}\text { Exclude } \\ \text { Survey FE }\end{array} & \begin{array}{l}\text { Cluster SE } \\ \text { at Reform } \\ \text { Level }\end{array} & \begin{array}{l}\text { Include } \\ \text { Regional } \\ \text { Germany } \\ \text { Reforms }\end{array} & \begin{array}{l}\text { Exclude } \\ \text { Left- } \\ \text { right = 5 }\end{array} \\ & & & & & & \end{array}$

2nd stage. Outcome is left-right affiliation. 1 = far left, $5=$ center, 10 = far right

\begin{tabular}{|c|c|c|c|c|c|c|c|c|}
\hline Education age & $\begin{array}{l}0.262^{* * *} \\
(0.0978)\end{array}$ & $\begin{array}{l}0.191_{-}^{* *} \\
(0.0936)\end{array}$ & $\begin{array}{l}0.190_{-}^{*} \\
(0.114)\end{array}$ & $\begin{array}{l}0.296 * \\
(0.159)\end{array}$ & $\begin{array}{l}0.248^{* *} \\
(0.107)\end{array}$ & $\begin{array}{l}0.249^{* *} \\
(0.116)\end{array}$ & $\begin{array}{l}0.238^{* *} \\
(0.109)\end{array}$ & $\begin{array}{l}0.312^{* *} \\
(0.141)\end{array}$ \\
\hline \multicolumn{9}{|c|}{ 1st stage. Outcome is education age. } \\
\hline Reform & $\begin{array}{l}0.390^{* * *} \\
(0.0685)\end{array}$ & $\begin{array}{l}0.508 * * * \\
(0.0918)\end{array}$ & $\begin{array}{l}0.249 * * * \\
(0.0548)\end{array}$ & $\begin{array}{l}0.304= \\
(0.0777)\end{array}$ & $\begin{array}{l}0.315^{* * *} \\
(0.0594)\end{array}$ & $\begin{array}{l}0.316= \\
(0.0657)\end{array}$ & $\begin{array}{l}0.292^{* * *} \\
(0.0566)\end{array}$ & $\begin{array}{l}0.352= \\
(0.0727)\end{array}$ \\
\hline $\begin{array}{l}\text { F-Stat on } \\
\text { excluded } \\
\text { instrument }\end{array}$ & 33.44 & 30.64 & 20.66 & 15.30 & 28.13 & 21.15 & 26.66 & 24.23 \\
\hline ( $p$-value) & $<0.0001$ & $<0.0001$ & $<0.0001$ & 0.0001 & $<0.0001$ & 0.0003 & $<0.0001$ & $<0.0001$ \\
\hline $\mathbf{N}$ & 52,994 & 25,981 & 70,685 & 66,267 & 66,267 & 66,267 & 71,419 & 47,784 \\
\hline
\end{tabular}

Robust standard errors in parentheses are clustered at the birth year-reform level (except column 6$)$. The bandwidth is \pm 7 years. 
All regressions include gender controls, a quadratic of age, reform fixed effects, and survey wave fixed effects (except (5)).

All except column 4 include linear cohort trends that can vary at the reform level.

Column 1 includes Belgium, Denmark, France, Greece, Italy, Netherlands, Sweden, and UK. Column 2 includes France, Italy, Sweden, and UK.

Column 4 includes a common cohort trend that does not vary at the reform level.

$* * * p<0.01$

$* * p<0.05$

$* p<0.1$

Next in column 5, I exclude the survey wave fixed effect. In column 6, I cluster standard errors at the reform level instead of the baseline birth year-reform level. In column 7, I include the regional reforms in Germany that are utilized by Brunello et al. (2009), assuming that individuals were educated in the same region in which they lived at the time of the survey. Finally in column 8 , I exclude individuals who report a left-right political affiliation of 5 (centrist) in case they are fundamentally different in some way. As seen in columns 5-8 of Table 10, the magnitude of the estimated LATE changes only modestly for these robustness checks and the estimates remain significant at the $5 \%$ level.

Another issue is that there are a relatively large number of individuals, approximately $13 \%$ of the sample, who refuse to answer the political affiliation question. This could be an indication that the individual is not politically engaged. Recall that these individuals are dropped from the main analysis. Therefore, I alternatively include these individuals in the sample and create a dichotomous variable for refusal to answer the political affiliation question. I replace "ideology" with this dichotomous refusal variable ( 1 = refuse, 0 = answer) in Eq. 4 and estimate the model with 2 SLS. I do not find any statistical evidence that education affects the probability of refusing to answer this question. 22 Likewise, one may wonder if education significantly affects the probability responding with a " 5 " to the political ideology question given the large spike seen in Fig. 1. Using the same samples from Table 5, I replace "ideology" with a dichotomous dependent variable ( $1=$ ideology of 5, $0=$ other) and estimate the model with 2SLS. I find no evidence that education affects the probability of identifying as a political centrist. $\underline{23}$

As I am pooling reforms from many different countries, one may wonder whether it is one particular country that is driving the results. To investigate this issue I omit one country at a time from the sample and re-estimate the model. Appendix Table A4 shows that it is not any one country that is responsible for the estimated effect. The estimated first stage effect of the reform on education always stays between 0.284 and 0.346 . Also, although the precision of the estimated LATE changes depending on which country is omitted, the scale is always between 0.206 and 0.306 and always significant at conventional levels. 
Finally, I report a series of falsification tests. In appendix Table A5, I show RD estimates for six different false reform dates. In each case, I utilize the maximum bandwidth for the falsified reform dates that does not overlap with the true reform. For example, in column 1 of Table A5, I move each educational reform back in time by 4 years relative to the true reform dates. In column 2 of Table A5, I move each reform forward by 4 years. I then repeat this process for \pm 7 years and \pm 10 years relative to the true reform dates. $\underline{24}$ As seen in Table A5, I find no evidence that these false reform dates significantly affect educational attainment; the first stage point estimates on "reform" are near 0 and have large standard errors. Furthermore, the second stage effect of education on political affiliation is never statistically significant while the point estimates are sometimes negative and sometimes positive. Table A5 presents another set of falsification tests. In columns 1 and 2, I draw a random number from the uniform distribution over the interval of $[1917,1969]$ for each reform and assign this random year as the first affected birth cohort. 25 In contrast, in columns 3 and 4, I use the true reform dates but randomly assign a false level of educational attainment to each individual. $\underline{26}$ Once again, there is no evidence that these falsified reforms affect educational attainment or political ideology in columns 1 and 2. Likewise, there are no statistically significant findings for the falsified educational attainment in columns 3 and 4.

\subsection{Local linear fuzzy RD results}

$\underline{\text { Table } 11}$ reports the nonparametric local linear fuzzy RD results. Columns 1 and 2 of Table 11 show results for two different optimal bandwidth choices. Column 3 shows results when I manually set the bandwidth to approximately $50 \%$ of the optimal bandwidth ( \pm 5 years). Then, columns $4-5$ report results for bandwidths of 7 and 10 to compare with the main parametric results in Table 5 . The conventional and bias-corrected local linear results are statistically significant and similar in magnitude to the main parametric results in Section 4.1 when using the optimal bandwidths and conventional inference. 27 Results for the manual bandwidths in columns 3-5 are statistically significant at conventional levels only in some cases and statistical significance does not hold up when using the robust inference suggested by Calonico et al. (2014a). However, overall, the local linear results agree with the magnitude and sign of the parametric results of Section 4.1.

Table 11. Local linear fuzzy RD estimates.
(1)
(2)
(3)
(4)
(5)

\section{Structural estimates (2nd stage). Outcome is left-right affiliation}

$\begin{array}{llllll}\text { Conventional } & 0.303_{-}^{*} & 0.298_{-}^{*} & 0.353 & 0.285_{-}^{*} & 0.320_{-}^{*} \\ & (0.156) & (0.156) & (0.250) & (0.165) & (0.165) \\ \text { Bias-corrected } & 0.306_{*}^{* *} & 0.509^{* * *} & 0.516_{*}^{* *} & 0.431^{* * *} & 0.261\end{array}$




\begin{tabular}{llllll} 
& $\mathbf{( 1 )}$ & $\mathbf{( 2 )}$ & $\mathbf{( 3 )}$ & $\mathbf{( 4 )}$ & $\mathbf{( 5 )}$ \\
& $(0.156)$ & $(0.156)$ & $(0.250)$ & $(0.165)$ & $(0.165)$ \\
Robust & 0.306 & 0.509 & 0.516 & 0.431 & 0.261 \\
& $(0.277)$ & $(0.379)$ & $(0.554)$ & $(0.313)$ & $(0.285)$ \\
\multicolumn{7}{c}{ 1st stage. Outcome is education age. } & & \\
Reform & $0.262^{* * *}$ & $0.278^{* * *}$ & $0.265^{* * *}$ & $0.291^{* * *}$ & $0.236^{* * *}$ \\
& $(0.0658)$ & $(0.0699)$ & $(0.102)$ & $(0.0781)$ & $(0.0615)$ \\
N & 76,056 & 76,056 & 37,558 & 56,842 & 85,344 \\
BW type & $\mathrm{CV}$ & $\mathrm{IK}$ & Manual & Manual & Manual \\
BW local poly & 9.0 & 8.14 & 5.0 & 7.0 & 10.0 \\
BW bias & 9.0 & 6.68 & 5.0 & 7.0 & 10.0
\end{tabular}

Local linear regressions used for point estimators. Local quadratic regressions used for bias correction. Triangular kernel used in all cases. BW=bandwidth.

CV=optimal BW selected by cross-validation procedure (Ludwig \& Miller, 2007)

IK=optimal BW selected according to method of Imbens and Kalyanaraman (2012).

All estimates are generated using the rdrobust package in Stata. Conventional 1st stage estimates are reported. $* * * p<0.01$

$* * p<0.05$,

$*_{p}<0.1$

\section{Conclusion}

In this article, I use data from 11 European countries to identify the effect of increasing educational attainment on political ideology as measured by self-placement on a left-right scale. Following a technique now well established in the literature, I instrument for educational attainment with 18 compulsory education laws that increased the minimum school leaving age in these 11 countries during 20th century Europe. This provides an advantage over previous work that has examined the link between education and political ideology as I am able to produce the first causal estimates of the education moving some individuals along the political spectrum. Furthermore, these results also add to the growing literature concerning the non-pecuniary effects of education. Overall, I find robust evidence that an extra year of education moves the average reform complier to the right of the political continuum by approximately $5 \%$.

Previous work provides conflicting theoretical predictions concerning the effect of educational attainment on political ideology. The self-interest thesis predicts that individuals will move to the right with more education whereas the developmental thesis predicts that individuals will move to the left with more education. The socialization thesis, on the other hand, predicts that the effect of 
educational attainment will depend upon the values of the society. In the socialization theory, education will tend to move individuals to the right in more right-leaning societies and to the left in more left-leaning societies. In the present study, when pooling all of the reforms, I find that education moves individuals to the right on average. An analysis of each country independently shows that the strongest results occur where previous research has documented a positive return to earnings from the educational reforms. Education appears to have no causal effect on left-right political affiliation in countries where previous research has shown reforms to be ineffective in increasing earnings. This suggests that the likely causal mechanism is that education increases earnings, which then moves individuals to the right; this is consistent with the self-interest thesis.

This study adds to the growing evidence that individuals tend to support political ideologies that are aligned with one's own self-interest. Doherty, Gerber, and Green (2006) show that larger lottery winnings leads to less support of redistribution and more support of eliminating the estate tax. Likewise, Powdthavee and Oswald (2014) show that lottery winners increase their probability of voting right by approximately 4 percentage points. Oswald and Powdthavee (2010) empirically show that having a daughter moves one to the political left and having a son moves one to the political right, and theoretically shows why this can be in one's self-interest. In their sample of individuals from the UK, a parent is approximately 2 percentage points more (less) likely to vote left for each daughter (son). Thus, the scale of the LATE herein is about the same size as the estimated effect from Powdthavee and Oswald (2014) and twice the size of that from Oswald and Powdthavee (2010). However, one may expect the effect to be comparatively larger in the present case because the survey is taking place typically many years after the educational reform treatment and it may take some time for political views to evolve whereas Powdthavee and Oswald (2014) and Oswald and Powdthavee (2010) are identifying the more immediate effects on political ideology.

As in any instrumental variables identification strategy, these results apply for the specific instrument utilized and for the specific subgroup of individuals who are affected by the instrument. These compliers in this context would come from the lower end of the schooling distribution. Therefore, we should not use these results to infer what would happen in a very different context, for example the United States, under a different compulsory education reform. Similarly, these results cannot speak to the causal effect of education at the higher end of the educational attainment distribution such as the effect on political identity of treating individuals with another year of college. One would need a different instrument that affects individuals in this range of education to answer this question.

Finally, the results in this paper support the assessment of Bauer et al. (2015)that there can be problems with observational studies linking education to left-right identity. I find a positive association 
between educational attainment and left-wing political ideology when failing to account for the endogeneity of education. An analysis that treats education as exogenous will likely suffer from omitted variables bias and the results herein show that the extent of the bias can be significant. Furthermore, there are reasons to believe in this context that multiple omitted variables may play a role and they may work in opposite directions. Thus, I would caution against inferring causality from studies that do not have an identification strategy to overcome this omitted variables problem.

\section{Acknowledgment}

I thank 3 anonymous reviewers for comments that have greatly improved the quality of the paper.

\section{Appendix}

Table A1. Reforms from the literature.

\begin{tabular}{|c|c|c|c|c|c|}
\hline Country/region & Study & Reform date & Gender & 1st stage & $\begin{array}{l}\text { Ln earnings } \\
\text { effect }\end{array}$ \\
\hline Denmark & $\underline{\text { Arendt (2005) }}$ & 1971 & Men & 0.262 & $\mathrm{~N} / \mathrm{A}$ \\
\hline Denmark & Arendt (2005) & 1971 & Women & 0.166 & N/A \\
\hline England, Wales & $\underline{\text { Clark and Royer (2013) }}$ & 1947 & All & $0.450^{* * *}$ & $\mathrm{~N} / \mathrm{A}$ \\
\hline England, Wales & $\underline{\text { Devereux and Hart (2010) }}$ & 1947 & All & $0.506^{* * *}$ & 0.021 \\
\hline England, Wales & $\underline{\text { Devereux and Hart (2010) }}$ & 1947 & Men & $0.47^{* * *}$ & $0.037 \stackrel{* *}{-}$ \\
\hline England, Wales & $\underline{\text { Devereux and Hart (2010) }}$ & 1947 & Women & $0.55^{* * *}$ & -0.003 \\
\hline England, Wales & Clark and Royer (2013) & $1972 / 73$ & All & $0.353^{* * *}$ & $\mathrm{~N} / \mathrm{A}$ \\
\hline England, Wales & Grenet (2013) & $1972 / 73$ & Women & $0.310^{* * *}$ & $0.067^{* * *}$ \\
\hline England, Wales & Grenet (2013) & $1972 / 73$ & Men & $0.267^{* * *}$ & $0.069 * * * *$ \\
\hline France & Albouy and Lequien (2009) & 1937 & All & 0.11 & N/A \\
\hline France & Albouy and Lequien (2009) & 1967 & All & $0.280^{* * *}$ & N/A \\
\hline France & Grenet (2013) & 1967 & Women & $0.274^{* * *}$ & -0.007 \\
\hline France & Grenet (2013) & 1967 & Men & $0.263^{* * *}$ & -0.004 \\
\hline Great Britain & $\underline{\text { Oreopoulos (2006a) }}$ & 1947 & All & $0.436^{* * *}$ & $0.145^{* *}$ \\
\hline Great Britain & $\underline{\text { Oreopoulos (2008) }}$ & 1947 & All & $0.408^{* * *}$ & 0.066 \\
\hline Ireland & Callan and Harmon (1999) & 1972 & Men & Not reported $\underline{b}$ & $0.10^{* * *}$ \\
\hline Italy & $\begin{array}{l}\text { Brandolini and Cippolone } \\
\underline{(2002)}\end{array}$ & 1963 & Women & $0.124 \stackrel{* * *}{\longleftarrow}$ & $0.207^{* * *}$ \\
\hline
\end{tabular}




\begin{tabular}{|c|c|c|c|c|c|}
\hline Country/region & Study & Reform date & Gender & 1st stage & $\begin{array}{l}\text { Ln earnings } \\
\text { effect }\end{array}$ \\
\hline Italy & Di Pietro and Delprato (2009) & 1963 & Men & $1.69 *$ & N/A \\
\hline Italy & Flabbi (1999) & 1963 & Men & Not reported & $0.053 * *$ \\
\hline Italy & $\underline{\text { Flabbi (1999) }}$ & 1963 & Women & Not reported & $0.030^{* * *}$ \\
\hline N. Ireland & Oreopoulos (2006a) & 1957 & All & $0.391^{* * *}$ & $0.187^{* *}$ \\
\hline N. Ireland & Oreopoulos (2008) & 1957 & All & $0.444^{* * *}$ & $0.18^{* * *}$ \\
\hline Netherlands & van Kippersluis et al. (2011) & 1928 & Men & $0.669 *$ & N/A \\
\hline Netherlands & Levin and Plug (1999) & $\begin{array}{l}1947,1950 \\
1975\end{array}$ & Men & $-0.168,-0.399,-1.927^{* * *}$ & $0.064 *$ \\
\hline Spain & Pons and Gonzalo (2002)c & 1970 & Men & $0.82,0.72_{-}^{*}$ & -0.015 \\
\hline Sweden & Meghir and Palme (2005) & 1962 & All & $0.298^{* * *}$ & 0.0142 \\
\hline Sweden & Hjalmarsson et al. (2015) & 1962 & Men & $\begin{array}{l}0.588^{* * *} \text { (no municipality } \\
\mathrm{FE} \text { ) }\end{array}$ & N/A \\
\hline Sweden & Hjalmarsson et al. (2015) & 1962 & Women & $\begin{array}{l}0.400^{* * *} \text { (no municipality } \\
\mathrm{FE} \text { ) }\end{array}$ & N/A \\
\hline Sweden & Hjalmarsson et al. (2015) & 1962 & Men & $0.328=($ municipality FE) & $\mathrm{N} / \mathrm{A}$ \\
\hline Sweden & Hjalmarsson et al. (2015) & 1962 & Women & $0.199^{* * *}$ (municipality FE) & $\mathrm{N} / \mathrm{A}$ \\
\hline UK & $\underline{\text { Harmon and Walker (1995) }}$ & $1947,1972 / 73$ & Men & $0.54_{-}^{*}, 0.11_{-}^{*}$ & $0.15^{* *}$ \\
\hline UK & Oreopoulos (2006a) & $1947 / 1957$ & All & $0.397^{* * *}$ & $0.149^{* * *}$ \\
\hline UK & Oreopoulos (2008) & $1947 / 1957$ & All & $0.44 * *$ & $0.105^{* * *}$ \\
\hline $\begin{array}{l}\text { aOreopoulos }(200 \\
\text { bCallan and Harm } \\
\text { regressions. }\end{array}$ & $\begin{array}{l}\text { 08) is a corrigendum to Oreop } \\
\text { non (1999) state that the refor }\end{array}$ & $\frac{\text { oulos }(2006 a)}{m \text { is not a valid }}$ & instrumer & nt and they do not use it & their final II \\
\hline $\begin{array}{l}\text { cPons and Gonzal } \\
\text { regressions. } \\
*_{*} *_{p}<0.01 \\
*_{p}<0.05 \\
*_{p}<0.1\end{array}$ & lo (2002) state that the reform & $n$ is not a valid $i$ & strument & and they do not use it ir & their final IV \\
\hline
\end{tabular}

Table A2. Left-right placement by country for individuals leaving full-time education at 21 years or older.

\begin{tabular}{llll} 
Country & N & Mean & Std. Dev. \\
\hline Austria & 824 & 5.38 & 2.02 \\
Belgium & 3346 & 5.04 & 1.85 \\
Denmark & 4974 & 5.20 & 2.10
\end{tabular}




$\begin{array}{llll}\text { Country } & \text { N } & \text { Mean } & \text { Std. Dev. } \\ \text { Greece } & 1808 & 5.06 & 2.08 \\ \text { France } & 1959 & 4.80 & 1.98 \\ \text { Ireland } & 1129 & 5.45 & 1.81 \\ \text { Italy } & 707 & 5.15 & 2.56 \\ \text { Netherlands } & 6566 & 4.80 & 1.96 \\ \text { Spain } & 1032 & 4.44 & 2.01 \\ \text { Sweden } & 3994 & 5.50 & 2.15 \\ \text { United Kingdom } & 2068 & 5.07 & 1.87\end{array}$

Note: This summarizes the sample generated by a bandwidth of \pm 10 years.

Table A3. 2SLS regression results, countries grouped by left-right placement.

$\begin{array}{llll}\text { (1) (2) (3) (5) } & \text { (2) }\end{array}$

Included countries Left Right Center Left and center Right and center

2nd stage. Outcome is left-right affiliation. 1 = far left, 5 = center, 10 = far right

Education age

$\begin{array}{lllll}0.0800 & 0.390_{-}^{*} & 0.294 & 0.173 & 0.344^{* *} \\ (0.153) & (0.208) & (0.194) & (0.120) & (0.142)\end{array}$

1st stage. Outcome is education age.

$\begin{array}{llllll}\text { Reform } & 0.345^{* * *} & 0.296^{* * *} & 0.317^{* * *} & 0.332^{* * *} & 0.306^{* * *} \\ & (0.120) & (0.102) & (0.0771) & (0.0727) & (0.0657) \\ \text { F-Stat on excluded instrument } & 8.27 & 8.42 & 16.93 & 20.86 & 21.68 \\ \text { (p-value) } & 0.0051 & 0.0050 & 0.0001 & <0.0001 & <0.0001 \\ \text { N } & 22,727 & 24,023 & 19,517 & 42,244 & 43,540\end{array}$

Robust standard errors in parentheses are clustered at the birth year-reform level. The bandwidth is \pm 7 years. All regressions include gender controls, a quadratic of age, linear cohort trends that can vary at the reform level, reform fixed effects, and survey wave fixed effects.

Left group = France, Netherlands, and Spain. Right group = Austria, Denmark, Ireland, Italy, and Sweden. Center group=Belgium, Greece, and UK.

$* * * p<0.01$,

$* * p<0.05$,

$*_{p}<0.1$

\section{Table A4. Regression results leaving out 1 country.}

\begin{tabular}{lllll}
$\begin{array}{l}\text { Omitted } \\
\text { country }\end{array}$ & $\mathbf{N} \quad \begin{array}{l}\text { 2nd stage effect of education age } \\
\text { on political ideology }\end{array}$ & $\begin{array}{l}\text { 1st stage effect of reform on } \\
\text { education age }\end{array}$ & $\begin{array}{l}\text { 1st stage } \text { F-Stat on } \\
\text { excluded instrument }\end{array}$ \\
\hline Austria & 61,864 & $0.206^{* *}(0.0961)$ & $0.342^{* * *}(0.0630)$ & 29.39 \\
\hline
\end{tabular}




\begin{tabular}{|c|c|c|c|c|}
\hline $\begin{array}{l}\text { Omitted } \\
\text { country }\end{array}$ & $\mathbf{N}$ & $\begin{array}{l}\text { 2nd stage effect of education age } \\
\text { on political ideology }\end{array}$ & $\begin{array}{l}\text { 1st stage effect of reform on } \\
\text { education age }\end{array}$ & $\begin{array}{l}\text { 1st stage } F \text {-Stat on } \\
\text { excluded instrument }\end{array}$ \\
\hline Belgium & 60,887 & $0.251_{*}^{* *}(0.107)$ & $0.327^{* * *}(0.0641)$ & 26.10 \\
\hline Denmark & 61,174 & $0.271 * *(0.108)$ & $0.327^{* * *}(0.0606)$ & 29.04 \\
\hline Greece & 61,639 & $0.206_{-}^{*}(0.108)$ & $0.313^{* * *}(0.0624)$ & 25.13 \\
\hline France & 59,519 & $0.296^{* *}(0.125)$ & $0.296^{* * *}(0.0598)$ & 24.44 \\
\hline Ireland & 61,464 & $0.251^{* *}(0.105)$ & $0.346^{* * *}(0.0630)$ & 30.21 \\
\hline Italy & 62,735 & $0.226_{-}^{*}(0.123)$ & $0.284^{* * *}(0.0593)$ & 22.92 \\
\hline Netherlands & 54,355 & $0.211_{-}^{*}(0.111)$ & $0.321^{* * *}(0.0656)$ & 23.93 \\
\hline Spain & 62,200 & $0.306^{* * *}(0.112)$ & $0.324^{* * *}(0.0602)$ & 29.05 \\
\hline Sweden & 60,075 & $0.239^{* *}(0.119)$ & $0.293^{* * *}(0.0626)$ & 21.94 \\
\hline \multicolumn{4}{|l|}{ Kingdom } & 20.45 \\
\hline $\begin{array}{l}\text { Robust stand } \\
\text { All regression } \\
\text { reform fixed } \\
* * *_{p}<0.01 \\
* *_{p}<0.05 \\
*_{p}<0.1\end{array}$ & $\begin{array}{l}\text { errors } \\
\text { nclude } \\
\text { ects, an }\end{array}$ & $\begin{array}{l}\text { in parentheses are clustered at } t \\
\text { gender controls, a quadratic of ag } \\
\text { id survey wave fixed effects. }\end{array}$ & $\begin{array}{l}\text { birth year-reform level. The } \\
\text { linear cohort trends that ca }\end{array}$ & $\begin{array}{l}\text { bandwidth is } \pm 7 \text { years. } \\
n \text { vary at the reform leve }\end{array}$ \\
\hline
\end{tabular}

\section{Table A5. Falsification tests, reform dates moved backward and forward in time.}
(1)
(2)
(3)
(4)
(5)
(6)

2nd stage. Outcome is left-right affiliation. 1 = far left, $5=$ center, 10 = far right

Education age

$\begin{array}{llllll}-0.383 & -0.303 & 0.0947 & 0.726 & -0.361 & 0.546 \\ (0.571) & (4.04) & (0.435) & (0.958) & (0.453) & (0.843)\end{array}$

1st stage. Outcome is education age.

$\begin{array}{lllllll}\text { Reform } & -0.0774 & 0.0343 & 0.0726 & 0.0517 & 0.0788 & 0.0382 \\ & (0.0693) & (0.0663) & (0.0534) & (0.0518) & (0.0504) & (0.0440) \\ \text { F-Stat on excluded instrument } & 1.25 & 0.268 & 1.85 & 0.996 & 2.45 & 1.00 \\ \mathbf{N} & 36,129 & 39,641 & 59,678 & 71,224 & 77,728 & 101,114 \\ \text { False reform year } & -4 & 4 & -7 & 7 & -10 & 10 \\ \text { Bandwidth } & 4 & 4 & 7 & 7 & 10 & 10\end{array}$

Robust standard errors in parentheses are clustered at the birth year-reform level. The bandwidth is \pm 7 years. All regressions include gender controls, a quadratic of age, linear cohort trends that can vary at the reform level, reform fixed effects, and survey wave fixed effects. 


\section{Table A6. Falsification tests, random reform years and random educational attainment.}
(1)
(2)
(3)
(4)

2nd stage. Outcome is left-right affiliation. 1 = far left, 5 = center, 10 = far right

$\begin{array}{lllll}\text { Education age } & -4.83 & 7.00 & -12.34 & -2.82 \\ & (11.62) & (38.20) & (130.44) & (7.10) \\ \text { 1st stage. Outcome is education age } & & & & \\ \text { Reform } & 0.0292 & -0.0123 & -0.00634 & -0.0231 \\ & (0.0694) & (0.0673) & (0.0669) & (0.0568) \\ \text { F-Stat on excluded instrument } & 0.177 & 0.0332 & 0.0090 & 0.165 \\ \text { N } & 47,709 & 67,911 & 66,267 & 94,694 \\ \text { Reform year } & \text { Random } & \text { Random } & \text { Actual } & \text { Actual } \\ \text { Education } & \text { Actual } & \text { Actual } & \text { Random } & \text { Random } \\ \text { Bandwidth } & 7 & 10 & 7 & 10\end{array}$

Robust standard errors in parentheses are clustered at the birth year-reform level. The bandwidth is \pm 7 years. All regressions include gender controls, a quadratic of age, linear cohort trends that can vary at the reform level, reform fixed effects, and survey wave fixed effects.

$* * * p<0.01$,

$* * p<0.05$,

$*_{p}<0.1$ 


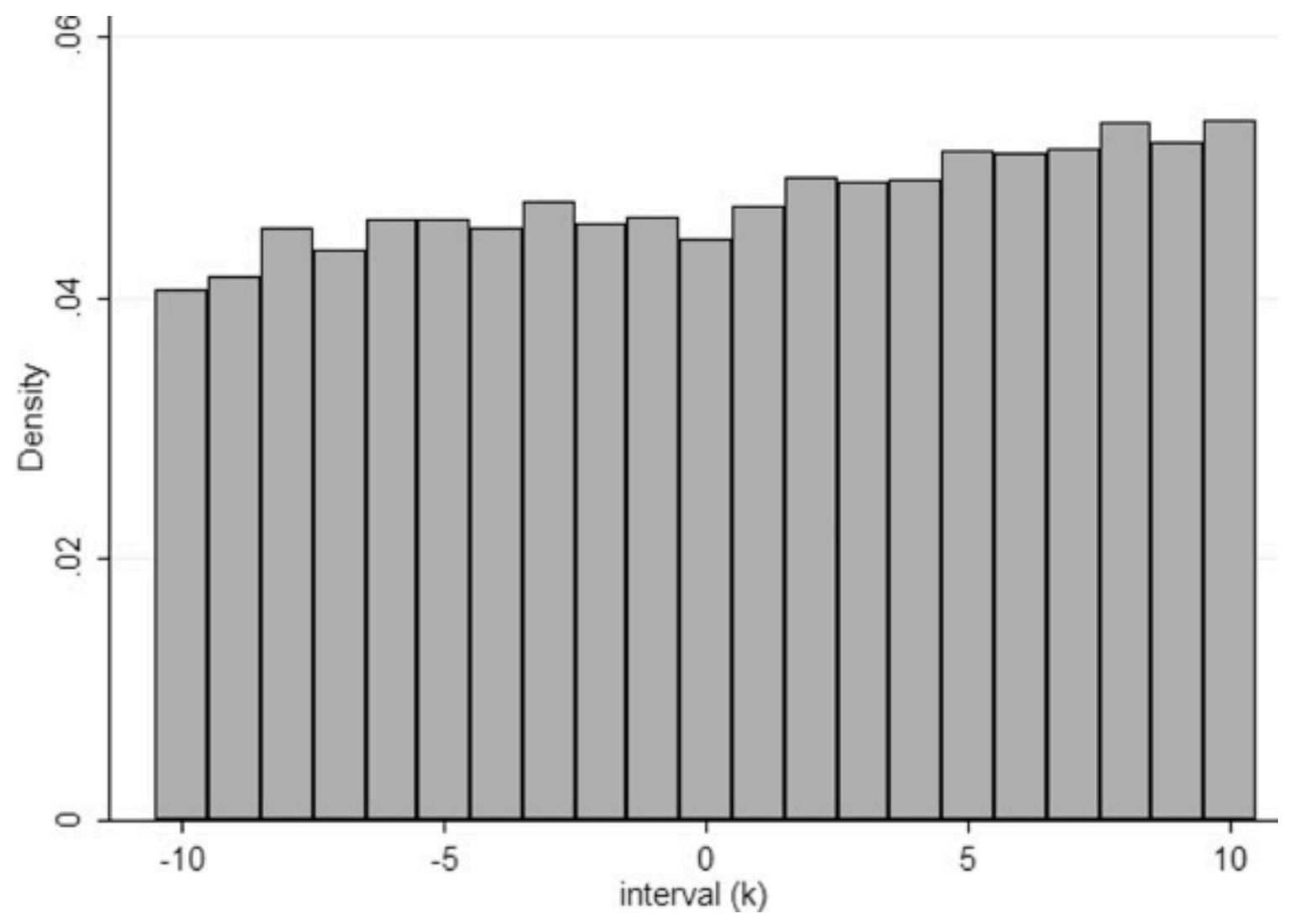

Fig. A1. Density of the forcing variable. Note: Histogram shows the density of observations according to birth cohort. Interval $(k)=0$ corresponds to the pivot cohort.

Appendix B. Supplementary materials

\section{Research data for this article}

\section{Open Data}

for download under the $\underline{\text { C } ~ B Y ~ l i c e n c e ~}$

application 1

(DOCX, 20KB)

Download data

About research data

\section{References}

Aakvik et al., 2010. A. Aakvik, K.G. Salvanes, K. Vaage. Measuring heterogeneity in the returns to education using an

education reform. European Economic Review, 54 (4) (2010), pp. 483-500

Acemoglu and Angrist, 2001. D. Acemoglu, J. Angrist. How large are human-capital Externalities? Evidence from compulsory

schooling laws, Vol. 15, MIT Press, Cambridge and London (2001)

Albouy and Lequien, 2009. V. Albouy, L. Lequien. Does compulsory education lower mortality? Journal of Health

Economics, 28 (1) (2009), pp. 155-168 
Almond et al., 2010. D. Almond, J. Doyle Jr., A. Kowalski, H. Williams. Estimating marginal returns to medical care: evidence from at-risk newborns. Quarterly Journal of Economics, 125 (2) (2010), pp. 591-634

Angrist and Krueger, 1991. J.D. Angrist, A.B. Krueger. Does Compulsory School Attendance Affect Schooling and Earnings? Quarterly Journal of Economics, 106 (4) (1991), pp. 979-1014

Angrist and Pischke, 2009. J.D. Angrist, J. Pischke. Mostly harmless Econometrics: an empiricist's companion. Princeton University Press, Princeton and Oxford (2009)

Arendt, 2005. J.N. Arendt. Does education cause better health? A panel data analysis using school reforms for identification. Economics of Education Review, 24 (2) (2005), pp. 149-160

Barreca et al., 2011. A. Barreca, M. Guldi, J. Lindo, G. Waddell. Saving babies? Revisiting the effect of very low birth weight classification. The Quarterly Journal of Economics, 126 (4) (2011), pp. 2117-2123

Barreca et al., 2016. A. Barreca, J. Lindo, G. Waddell. Heaping-induced bias in regression-discontinuity designs. Economic Inquiry, 54 (1) (2016), pp. 268-293

Bauer et al., 2015. P.C. Bauer, P. Barbera, K. Ackermann, A. Venetz. Is the left-right scale a valid measure of ideology? Individual-level variation in associations with 'left' and 'right' and left-right self-placement. SSRN (2015) Working Paper.http://ssrn.com/abstract=2467595

Black et al., 2008. S.E. Black, P.J. Devereux, K.G. Salvanes. Staying in the classroom and out of the maternity ward? The effect of compulsory schooling laws on teenage births. Economic Journal, 118 (530) (2008), pp. 1025-1054

Borgonovi et al., 2010. F. Borgonovi, B. d'Hombres, B. Hoskins. Voter turnout, information acquisition and education: Evidence from 15 European countries. The B.E. Journal of Economic Analysis \& Policy, 10 (1) (2010), pp. 1-31. art. 90

Brandolini and Piero, 2002. Brandolini, A., \& Piero, C. (2002). Return to education in Italy 1992-1997. Working Paper. Central Bank of Italy, Research Department, Rome, Italy.

Brunello et al., 2009. G. Brunello, M. Fort, G. Weber. Changes in compulsory schooling, education and the distribution of wages in Europe. Economic Journal, 119 (536) (2009), pp. 516-539

Brunello et al., 2013. G. Brunello, D. Fabbri, M. Fort. The causal effect of education on body mass: Evidence from Europe. Journal of Labor Economics, 31 (1) (2013), pp. 195-223

Callan and Harmon, 1999. T. Callan, C. Harmon. The economic return to schooling in Ireland. Labour

Economics, 6 (4) (1999), pp. 543-550

Calonico et al., 2014a. S. Calonico, M. Cattaneo, R. Titiunik. Robust nonparametric confidence intervals for regression discontinuity designs. Econometrica, 82 (6) (2014), pp. 2295-2326

Calonico et al., 2014b. S. Calonico, M. Cattaneo, R. Titiunik. Robust data-driven inference in the regression-discontinuity design. The Stata Journal, 14 (4) (2014), pp. 909-946

Cassette et al., 2013. A. Cassette, E. Farvaque, J. Hericourt. Two-round elections, one-round determinants? Evidence from the French municipal elections. Public Choice, 156 (3-4) (2013), pp. 563-591

Cattaneo et al., 2016a. M. Cattaneo, M. Jansson, X. Ma. Simple local regression distribution estimators with an application to manipulation testing. (2016) Working paper

Cattaneo et al., 2016b. M. Cattaneo, M. Jansson, X. Ma. rddensity: Manipulation testing based on density discontinuity. (2016). Working paper 
Clark and Royer, 2013. D. Clark, H. Royer. The effect of education on adult mortality and health: Evidence from Britain. American Economic Review, 103 (6) (2013), pp. 2087-2120

Dee, 2004. T.S. Dee. Are there civic returns to education? Journal of Public Economics, 88 (9-10) (2004), pp. 1697-1720 Devereux and Hart, 2010. P.J. Devereux, R.A. Hart. Forced to be Rich? Returns to Compulsory Schooling in Britain. The Economic Journal, 120 (2010), pp. 1345-1364

Di Pietro and Delprato, 2009. G. Di Pietro, M. Delprato. Education and civic outcomes in Italy. Public Finance Review, 37 (4) (2009), pp. 421-445

Doherty et al., 2006. D. Doherty, A. Gerber, D. Green. Personal income and attitudes toward redistribution: A study of lottery winners. Political Psychology, 27 (3) (2006), pp. 441-458

Dunn, 2011. K. Dunn. Left-right identification and education in Europe: A contingent relationship. Comparative European Politics, 9 (3) (2011), pp. 292-316

Esping-Anderson, 1990. G. Esping-Anderson. The three worlds of welfare capitalism. Polity Press, Cambridge, UK (1990)

Esping-Andersen, 1999. G. Esping-Andersen. Social foundations of postindustrial economies. Oxford University

Press, Oxford (1999)

European Commission 2014. European Commission, (2014). Eurobarometer 77.2 (2012). TNS OPINION \& SOCIAL, Brussels

[Producer]. GESIS Data Archive, Cologne. ZA5598 Data file Version 4.0.0, doi: 10.4232/1.12032

Flabbi, 1999. L. Flabbi. Returns to schooling in Italy: OLS, IV, and gender differences. Università Bocconi (1999) Working Paper

Fort, 2006. M. Fort. Educational reforms across Europe: A toolbox for empirical research. (2006). Working Paper Gathmann et al., 2015. C. Gathmann, H. Jürges, S. Reinhold. Compulsory schooling reforms, education and mortality in twentieth century Europe. Social Science \& Medicine, 127 (0) (2015), pp. 74-82

Grenet, 2013. J. Grenet. Is extending compulsory schooling alone enough to raise earnings? Evidence from French and British compulsory schooling laws. The Scandinavian Journal of Economics, 115 (1) (2013), pp. 176-210 Harmon and Walker, 1995. C. Harmon, I. Walke. rEstimates of the economic return to schooling for the United Kingdom.

The American Economic Review, 85 (5) (1995), pp. 1278-1286

Hjalmarsson et al., 2015. R. Hjalmarsson, H. Holmlund, M.J. Lindquist. The Effect of education on criminal convictions and incarceration: Causal evidence from micro-data. Economic Journal, 125 (587) (2015), pp. 1290-1326

Imbens and Kalyanaraman, 2012. G. Imbens, K. Kalyanaraman. Optimal bandwidth choice for the regression discontinuity estimator. Review of Economic Studies, 79 (3) (2012), pp. 933-959

James, 2015. J. James. Health and education expansion. Economics of Education Review, 49 (2015), pp. 193-215 van Kippersluis et al., 2011. H. van Kippersluis, O. O'Donnell, E. van Doorslaer. Long-run returns to education: does schooling lead to an extended old age? Journal of Human Resources, 46 (4) (2011), pp. 695-721

Lee and Lemieux, 2010. D.S. Lee, T. Lemieux. Regression discontinuity designs in economics. Journal of Economic Literature, 48 (2) (2010), pp. 281-355

Levin and Plug, 1999. J. Levin, E. Plug. Instrumenting education and the returns to schooling in the Netherlands. Labour

Economics, 6 (4) (1999), pp. 521-534

Lleras-Muney, 2005. A. Lleras-Muney. The relationship between education and adult mortality in the United States. Review of Economic Studies, 72 (1) (2005), pp. 189-221 
Lochner and Moretti, 2004. L. Lochner, E. Moretti. The effect of education on crime: Evidence from prison inmates, arrests, and self-Reports. American Economic Review, 94 (1) (2004), pp. 155-189

Ludwig and Miller, 2007. J. Ludwig, D. Miller. Does head start improve children's life chances? Evidence from a regression discontinuity design. Quarterly Journal of Economics, 122 (1) (2007), pp. 159-208

Machin et al., 2011. S. Machin, O. Marie, S. Vujic. The crime reducing effect of education. Economic Journal, 121 (552) (2011), pp. 463-484

McCrary, 2008. J. McCrary. Manipulation of the running variable in the regression discontinuity design: A density test. Journal of Econometrics, 142 (2) (2008), pp. 698-714

Meghir and Palme, 2005. C. Meghir, M. Palme. Educational reform, ability, and family background. American Economic Review, 95 (1) (2005), pp. 414-424

Meyer, 2015. A. Meyer. Does education increase pro-environmental behavior? Evidence from Europe. Ecological Economics, 116 (0) (2015), pp. 108-121

Milligan et al., 2004. K. Milligan, E. Moretti, P. Oreopoulos. Does education improve citizenship? Evidence from the United States and the United Kingdom. Journal of Public Economics, 88 (9-10) (2004), pp. 1667-1695

Oreopoulos, 2006a. P. Oreopoulos. Estimating average and local average treatment effects of education when compulsory schooling laws really matter. American Economic Review, 96 (1) (2006), pp. 152-175

Oreopoulos, 2006b. P. Oreopoulos. The compelling effects of compulsory schooling: Evidence from Canada. Canadian Journal of Economics, 39 (1) (2006), pp. 22-52

Oreopoulos, 2008. Oreopoulos, P. (2008). Estimating Average and Local Average Treatment Effects of Education When Compulsory Schooling Laws Really Matter: Corrigendum. (Internet Only Corrigendum to Oreopoulos, 2006a). August 2008.

Oreopoulos and Salvanes, 2011. P. Oreopoulos, K.G. Salvanes. Priceless: The nonpecuniary benefits of schooling. Journal of Economic Perspectives, 25 (1) (2011), pp. 159-184

Oswald and Powdthavee, 2010. A. Oswald, N. Powdthavee. Daughters and left-wing voting. The Review of Economics and Statistics, 92 (2) (2010), pp. 213-227

Persson et al., 2016. M. Persson, K. Lindgren, S. Oskarsson. How does education affect adolescents' political development? Economics of Education Review, 53 (2016), pp. 182-193

Phelan et al., 1995. J. Phelan, B.G. Link, A. Stueve, R.E. Moore. Education, social liberalism, and economic conservatism:

Attitudes toward homeless people. American Sociological Review, 60 (1) (1995), pp. 126-140

Pons and Gonzalo, 2002. E. Pons, M. Gonzalo. Returns to schooling in Spain: How reliable are instrumental variable estimates? Labour, 16 (4) (2002), pp. 747-770

Powdthavee and Oswald, 2014. Powdthavee, N., \& Oswald, A. (2014). Does money make people right-wing and inegalitarian? A longitudinal study of lottery winners, IZA Discussion Paper Series, No. 7934.

Roodman, 2011. D. Roodman. Estimating fully observed recursive mixed-process models with cmp. Stata Journal, 11 (2) (2011), pp. 159-206

Sakurai and Menezes-Filho, 2008. S.N. Sakurai, N.A. Menezes-Filho. Fiscal policy and reelection in Brazilian municipalities. Public Choice, 137 (1--2) (2008), pp. 301-314

Siedler, 2010. T. Siedler. Schooling and citizenship in a young democracy: Evidence from postwar Germany. The Scandinavian Journal of Economics, 112 (2) (2010), pp. 315-338 
Stock et al., 2002. J. Stock, J. Wright, M. Yogo. A survey of weak instruments and weak identification in generalized method of moments. Journal of Business and Economic Statistics, 20 (4) (2002), pp. 518-529

Veiga and Veiga, 2004. F.J. Veiga, L.G. Veiga. The determinants of vote intentions in Portugal. Public Choice, 118 (3-4) (2004), pp. 341-364

Weakliem, 2002. D.L. Weakliem. The effects of education on political opinions: An international study. International Journal of Public Opinion Research, 14 (2) (2002), pp. 141-157

Weil, 1985. F. Weil. The variable effects of education on liberal attitudes: A comparative- historical analysis of antisemitism using public opinion survey data. American Sociological Review, 50 (4) (1985), pp. 458-474

Some studies find no effects of education on health (Albouy and Lequien, 2009; Clark and Royer, 2013) or inconclusive effects (Arendt, 2005). James (2015) finds effects for some health outcomes but not for others and Brunello et al. (2013) find an effect for females but no effect for males.

2The Eurobarometer wave numbers are: 62.1, 62.2, 63.1, 63.2, 64.3, 64.4, 65.1, 66.2, 66.3, 67.1, 67.2, 68.1, 68.2, $69.1,69.2,70.1,71.1,72.4,73.1,74.2,74.3,75.1,75.2,76.1$, and 77.2.

II do not include the smaller number of waves that take place exclusively in summer months because this would introduce more measurement error in the year of birth.

${ }_{4}^{4}$ Further details about the surveys are provided in Meyer (2015). Eurobarometer primary data files are publicly available from GESIS (for example, European Commission, 2014).

sIncluding individuals in the sample who report an age higher than 35 when stopping education only slightly changes point estimates across all specifications.

$\underline{6}$ Table 1 of Gathmann et al. (2015) list two early reforms that do not apply to this analysis. Denmark's 1903 reform first affected those born in 1890 whereas the earliest birth year in Denmark in the present sample is 1914. Similarly, Belgium's 1919 reform first affected those born in 1910 whereas earliest birth year in Belgium in the present sample is 1912.

기 exclude the regional level reforms from Finland because the within-country NUTS codes in some of the Eurobarometer surveys do not map cleanly into the Brunello et al. (2009) regions; definitions of withincountry NUTS regions change over time. I also exclude regional level reforms from Germany because I am not able to identify the region of birth. I discuss this further in Section 4.

sConsistent with Meyer (2015), I exclude individuals born in the pivot cohort from the sample because I cannot accurately identify whether or not they were treated with the reform.

Il also include robustness checks using multiple other bandwidths.

$\underline{10}$ Exogenous controls such as age and gender can help reduce the sampling variability in the RD estimates (Lee and Lemieux, 2010). Other potentially endogenous controls such as income that are simultaneously determined with educational attainment should not be included in the regression design (Angrist and Pischke, 2009).

11For the linear specification, $\gamma_{3}=\gamma_{4}=0$.

12 For the linear specification, $\lambda_{3}=\lambda_{4}=0$.

${ }^{13}$ Brunello et al. (2009) also includes similar interactions.

14 thank an anonymous referee for making this point.

15 However, as seen in appendix Fig. A1, I do not see any evidence of heaping at the pivot cohort when examining the density of the forcing variable. Likewise, the test suggested by Cattaneo, Jansson, and Ma (2016a) finds no evidence of a discontinuity in the density of the forcing variable at the pivot cohort. This test, implemented on a bandwidth of 7 by the rddensity command (Cattaneo, Jansson, \& Ma, 2016b) in Stata reports test statistics (in parentheses) for three approaches: conventional ( -0.217$)$, undersmoothed (0.0089), and robust bias-corrected (0.0747). Barreca, Lindo, and Waddell (2016) more deeply explore this issue of bias from heaping in the running variable. 
16) utilize the rdrobust package in Stata for all nonparametric local linear regressions (Calonico, Cattaneo, \& Titiunik, 2014b).

17Brunello et al. (2013) use a similar clustering strategy.

18) utilize Roodman's (2011) $\mathrm{cmp}$ program within Stata 14.1 to estimate the parameters of this system of equations.

${ }_{19}^{19}$ s emphasized by Esping-Anderson (1999), "readers should be warned that 'liberal' and 'conservative' are used here in their classical, European usage. Liberal therefore does not imply leftist, but rather a laissez-faire, neo-liberal view; conservative does not refer to 'whatever is not liberal', be it the Christian right or the Republican party, but to the European usage of the term."

20Another difference is that Meghir and Palme (2005) impute years of education from categorical education levels. 21 Results for these robustness checks from other bandwidths are available upon request.

22 Using the analogous specifications to columns 1 and 3 of Table 5 , the 2 nd stage coefficient on education is 0.0198 with a standard error of 0.0206 for a bandwidth of $10(n=109,238)$ and 0.0180 with a standard error of 0.0178 for a bandwidth of 7 ( $n=76,326)$.

${ }_{23}$ Using the analogous specifications to columns 1 and 3 of Table 5 , the 2 nd stage coefficient on education is 0.0016 with a standard error of 0.023 for a bandwidth of $10(n=94,694)$ and 0.013 with a standard error of 0.022 for a bandwidth of 7 ( $n=66,267)$.

${ }^{24}$ Grenet (2013) conducts similar falsification tests in moving the reforms forward or backward several years. 25This follows the fake reform falsification test from Borgonovi et al. (2010). I exclude Netherlands from this falsification test because the randomly selected years would cause the falsified reforms to overlap. 26) take the true observations on educational attainment for the entire sample and randomly assign each true observation to a different individual.

27-ne exception is the bias-corrected point estimate in column 2 is substantially larger than the others. 